\title{
EMPLOYEE PENSIONS IN COLLECTIVE BARGAINING
}

IN the United States the individual has traditionally borne the responsibility for providing adequate security against the hazards of his old age. This individual effort has often left areas of want unsatisfied. ${ }^{1}$ Government assistance has almost always been inadequate, ${ }^{2}$ and recipients have often been stigmatized as thriftless, improvident and lazy. ${ }^{3}$

Faced with the inadequacy of individual effort and the insufficiency or non-existence of government activity, men have resorted to private collective schemes in order to make secure their own futures. Until recently,

1. The problem of the "poor" has been with us, in the cities at least, since the days of the earliest colonies. See, e.g., Bridenanugir, Cities in tue Wilderness 78-85, 232-8, 391-8 (1938). In seventeenth-century Boston, for example, not only were problems of unemployment serious, but provisions for the care of the sick and aged were needed as well. Id. at 82.

In more recent times the individual's ability to provide for his own future has been seriously affected by a number of factors not directly within his control. Interest rates on savings accounts are declining while income taxes are increasing. See O'NEILL, MODERN Pension Plans 17-20 (1947). And greater life expectancy has increased the period for which provision must be made.

Individual savings are, of course, a source of old-age security, but effective saving is confined to that portion of the population with relatively high incomes. In 1947, for example, the aggregate of all families earning less than $\$ 2,000$ spent more than their total earned income. FEDERAl Reserve Board, 1948 Survey of Consumer Finances, cited at page 23 in Nathan, A National Economic Policy for 1949 (1949). In the same year, the uppermost ten per cent of income recipients were responsible for seventy-seven per cent of the year's total savings. Id. at 25 .

From time to time various government incentives have been suggested to encourage individual savings. See, e.g., Steinhaus, Financing Old Age (National Industrial Conference Board, Studies in Individual and Collective Security No. 4) c. IV (1948).

2. Until 1914, state government provision for the aged generally took the form of (1) relief provided to residents of almshouses or (2) outdoor relief furnished through county agencies. In 1914 Arizona enacted the first American old-age pension law. Hacker \& Kendrick, The United States Since 1865, p. 426 (3d ed. 1946). The statute was quickly declared unconstitutional in State Board of Control v. Buckstegge, 18 Ariz. 277, $158 \mathrm{Pac} .837$ (1916). The movement for old-age pensions in the states did not result in appreciable gains until the late twenties. HACKER \& Kendrick, Tue United States Sivce 1865, p. 426 (3d ed. 1946). Even then, the recipient generally had to show lack of other means of support. Ibid. It was not until 1935 that the federal old-age security program was adopted.

3. See, e.g., description in Federal Security Agency, Soctal Security in the United States 2 (1948); Hoffman, The Problem of Poverty ant Pensions in Old Agc, 14 Asr. J. Soc. 182 (1908).

Numerous attempts have been made to analyze "objectively" the factors which cattse need in oild age. See, e.g., Franked \& Fineisher, Tue Human Factor in Industny 310 (1920).

Since the last depression there has probably been a more wide-spread acceptance of the view that loss of the capacity for self-support might be due to reasons beyond the individual's control. Kahn, Function of Government in Relation to Economic Security, 32 AM. LAB. LEg. Rev. 120, 121 (1942). 
welfare and benefit programs established solely at the employer's initiative and welfare activities carried on solely by unions dominated the field of private group activity in social security. The past ten years, however, has witnessed a large scale merging of these hitherto generally separate streams of activity. This development has posed a number of important questions which relate to problems of the collective bargaining process, federal control, and the relationship between private activity and a more comprehensive national program of old-age security.

\section{HISTORICAL BACKGROUND}

\section{Employer Activity}

In the past, unions have been at times openly hostile to attempts by employers to establish retirement benefits. ${ }^{4}$ This opposition sprang from a belief, supported by experience, that a pension which an employer could grant or withhold at his discretion, and which the union had not helped to establish or administer could prove an effective weapon in combating union organization. ${ }^{5}$ Moreover, unions recognized that future pension benefits traded for present wage increases would be a poor bargain if the pensions were never realized because of the collapse of the company or the discontinuance of the plan.

Despite this union apathy or opposition, a number of company pension plans were unilaterally established. ${ }^{\circ}$ This number increased slowly ${ }^{7}$ and

4. See Latimer, Social Sectrity in Collective Bargaining in Proceednas of NEW York UNIVERSITY FIRST ANNUAL CoNfERENCE oN LAROR 5 (1948); NAtioisal Isidustrial Confrerence Board, Industrial Pensions in tae United States 16-17 (1925); Editorial, Contented Cows, Axrerican Feneratronalist 760 (Sept., 1923) reprinted in Saposs, Readings in Trade Unionisar 251-3 (1927).

It is no coincidence that early company pension plans were, on the whole, found in industries with little or no effective labor organization. Natrosral Indusman Co:srenence Board, Industrial Pensions in the United States 65 (1925).

5. This control could be openly exercised because of clauses frequently found in early company plans providing for forfeiture of benefits if an employee leit the service of his employer voluntarily or under the stress of influence "inimical to the company." National Industrial Conference Board, Industrial Pensions in tame Uimited States 64 (1925). A study in 1932 revealed that in one instance a program was revoled completely following a strike. 2 Latramer, Industriar Pewsion Systears 636 (1932). See also Minuts \& Ḿontgontery, Labor's Rises and Social Insurance 370-1 (1938).

Recent company plans give the employer much less discretion to revoke arbitrarily the

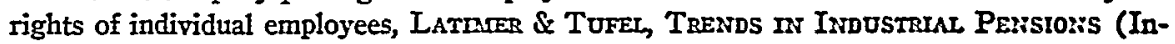
dustrial Relations Counselors, Industrial Relations Monograph No. 5) 43 (1940); and insurance companies will not issue group annuities if the employer attempts to retain the power to reduce or cause the forfeiture of annuities because of employee activity which is deemed prejudicial to the employer. O'NemL, Mfodern Pexsion Plass 129 (1947). There are, however, occasional vestigial remainders of the old type of clause. See, c.g., Untied States Rubber Co., Retirenrent Allowatece Plan axd Regulations 4 (Amended to July 9, 1947); Swift \& Co., Pension Pran 9 (1948).

6. The possible reasons which have caused employees to adopt pensions have always 
haltingly until the depression of the early thirties reversed the trend. A number of company plans were discontinued; in others, the amount of contributions supporting them was reduced. ${ }^{8}$ And after the Social Security

been numerous, National Industrial Conference Board, Industrual Pensions in tue United States c. II (1925); Gardner \& Weber, Pension, Bonus, and Profit-SuarING Plans 11-12 (1943); and the results difficult to measure, O'NeILL, MOdern PENS1ON Plans 74 (1947).

Employer enthusiasm for results has likewise varied. See, e.g., Nationar Industrual CONFERENCE BOARD, supra, c. III (1925). Although responses to questionnaires circulated in preparation of this Comment generally indicated a belief that pensions favorably affect such things as rate of turnover, employee morale, and public relations, some writers feel that employers fail to realize maximum advantages from pension programs because they do not adequately communicate facts of the programs to employees. See, generally, Brower, How Much Do Employee Benefits Cost, 11 Managenent Record 97, 98 (1949); Denker, Keeping Employes Informed and Interested, N.Y. Journal of Commerce, Sept. 23, 1948, § 2, p. 22, col. 1 ; Exton, Do Employees Appreciate Company Pensions, 88 Tnusts \& Estates 472 (1949); Fisher, Selling the Plan to Employees in Handbook ror Pension Planning c. 9 (1949); Redpath, Are Bentefit Systems Increasing Employes' Security?, N.Y. Journal of Commerce, May 29, 1946, §2, p. 22, col. 2.

7. The following table is compiled from Table 1, Latmaer \& TuFer, op. cit. supra note 5 , at 46 .

Number of Penston Plans by Period of Establishment

$\begin{array}{lc}\text { Year } & \text { Non-contrib- } \\ \text { Established } & 7 \\ 1875-1900 & 19 \\ 1901-05 & 24 \\ 1906-10 & 89 \\ 1911-15 & 104 \\ 1916-20 & 55 \\ 1921-25 & 20\end{array}$

Contributory
and Composite
1
2
3
10
17
16
38

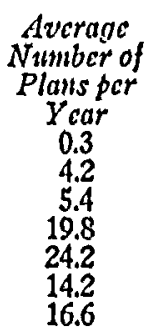

8. Slichter reports 418 plans in existence in 1929, of which forty-five had been abandoned by 1932. Slichter, The Pressing Problem of Old-Age Sectirity, N.Y. Times Magazine, Oct. 16, 1949, p. 9 at 66 , col. 3. A more limited survey made during the depression indicated that seven of the 118 concerns reporting pension programs had dropped them by 1934. National Industrial Conference Bonrd, Effect of tite Depression on Industrias Relations Programs 4 (1934). Eighteen of the 291 plans established after May 1, 1932 had been discontinued by Dec. 31, 1938. LATTMER \& TUFEL, op. cit. supra note 5, at 51. Variations in total employer contributions during the early part of the depression are shown in the following table:

\begin{tabular}{|c|c|}
\hline \multicolumn{2}{|c|}{ EATPIOYER CONTRIBUtTons to $P$} \\
\hline$Y e a r$ & Actual Contribution \\
\hline $\begin{array}{l}1929 \\
1930 \\
1931 \\
1932 \\
1933 \\
1934 \\
1935\end{array}$ & $\begin{array}{l}128 \\
124 \\
121 \\
113 \\
103 \\
123 \\
129\end{array}$ \\
\hline
\end{tabular}

Bureau of Foretgn and Donestic Conmerce, National Inconge and Product Statistics of the UNited States 1929-46 (Supplement to Survey of Current Business, July, 1947) 45, Table 34 (1947). 
Act of $1935,{ }^{9}$ existing and newly-established programs were made more restrictive in their coverage. These later plans often applied only to salaried employees and/or to those earning in excess of the $\$ 3,000$ maximum on which benefits are payable under the Social Security program. ${ }^{10}$

\section{Union Efforis}

At the same time, unions did not press for the establishment of pensions through collective bargaining. Many union officers felt that organized labor should concern itself primarily with wage and hour objectives. The huge expenditures of time and effort involved in these drives left unions with little energy for pension demands. In addition, early unions appealed primarily to younger workers, among whom problems of old-age dependency were not very compelling. ${ }^{11}$ Whatever efforts unions exerted took the form of pensions established at the union's initiative and supported exclusively

9. 49 StAT. 620 (1935), as amended, 42 U.S.C. $\$ 301$ (1946).

10. Jamison, Practical Aspects of Establishing and Administering Pension Plans in

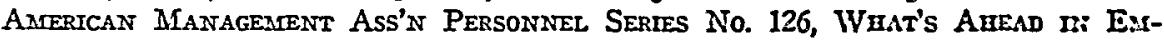
ployee Healtir and Pension Planning 3, S (1949). About ten per cent of the plans in existence in 1935 were discontinued within ten years because of the Social Security Act's provisions. Yoder, Personnel Mlanagenrent and Industrinl Relations 723 (1946). See also Effect of Social Security Act on Conzany Pensions, 50 Mlositmly Laros REVIEW 642-7 (1940).

From 1932 to 1938, however, more plans per year were established than at any previous time. LATTMER \& TUFE, op. cit. supra note 5, at 7. And total employer contributions for welfare purposes increased. Bureau of Foreign asd Dourestic Coscuretre, NAtronal Incone and Product Statistics of the United States 1929-46 (Supplement to Survey of Current Business, July, 19479) 45, Table 34 (1947). See also Natro:sul Industrial Conference Board Studies in Business Econoarics No. \&, Umiort Fienztir AND WELFARE Funds 23 (1947).

For a discussion of the possible effects of the proposed Social Security Act amendments see Fliess, Federal Social Security in Axrerrcan Mranagerrent Ass': Insumurice Series No. 81, Developarents in Soctal Securrty and Worgareats Coarpersatio: 11 (1949).

General methods of integrating company pension plans with the Social Security Act of 1935, 49 Stat. 620 (1935), as amended, 42 U.S.C. $\$ 301$ (1946) are discussed in LAtroser \& TUFEL, op. cit. supra note 5, c. IV: Specific methods and formulae are suggested in Gardner \& Weber, Pension, Bonus and Profit Stharing Plans 31-2, 40 (1943). Tax problems of integration are emphasized in Clark, Proftr Szarnsug and Persion Plans (Law and Taxes) \$26 (1946) and P-H Penston \& Profit Sharnang Serv. If 4062-77 (1947). For a case study of readjustments made in particular plans see Prricero:i UnIVERSTTY (Dep't of Economics and Social Institutions), The Effect of tHe Socral Security Act on Private Penstons (1939).

11. Latmier, Trade Union Penston Systears \&-9 (1932). William Green acknowledged the effectiveness of union-sponsored insurance programs in binding unions together, but emphasized their secondary importance in the union movement. GneEn, Uwio: Insurance quoted in Saposs, Readings in Trade Unionisar 331-2 (1927). Lilievise, Samuel Gompers emphasized immediate wage and hour objectives, REed, Tre LAzos Philosophy of SAaruel GoMrpers 16-18 (1930), but urged that union-sponsored welfare plans were preferable to compulsory social insurance. Rosenthal, Union-Mfanagenem W/ $\mathrm{Cl}$ fare Plans, 62 Q.J. EcoN. 64 (1947). 
by assessments on members. ${ }^{12}$ And even these efforts were regarded as charity. ${ }^{13}$

This type of union-sponsored plan expanded slowly. Many arrangements proved short-lived, as unions, for the most part, tended to underestimate the large expenses involved in any pension program. Union leaders were not always able to convince members that large reserves were necessary to meet successfully the increasing liabilities of a pension plan in the later years of its operation. ${ }^{14}$ And wages in most trades were inadequate to permit accumulation of funds sufficient to support adequate benefits. Hence, although members' earnings and contributions to the plans increased, union finances were unable to keep pace with the growing numbers of aged and disabled who were entitled to benefits. ${ }^{15}$ Moreover, these special pension funds were occasionally diverted to other purposes. ${ }^{16}$

It was not surprising, therefore, that unions began to lose interest in pension schemes. After World War I, few new pension plans were initiated. In the years of immediate post-war prosperity, problems of old-age security did not seem important. ${ }^{17}$ And in fact, some unions terminated their pension programs altogether. Still others imposed restrictions designed to reduce the number and amount of claims which could be made against the fund.18 As a result, only ten international unions had pension plans in operation by the beginning of 1930,19 and in 1933, under the impact of the depression,

12. In 1905 the Granite Cutters established the first pension plan of a wholly American union under which benefits were actually paid. Previously two unions had established plans, but no benefits were ever paid under them. Latimer, Trade Union Pension SYsTEMs 21 (1932). For a brief contemporary account of early trade union benefit activitics see Hearings before House Committee on Labor on H.J. Res. 159, 64th Cong., 1st Sess. 276-303 (1916).

13. Latramer, Trade Union Pension Systems 11, 21 (1932).

14. Id. at 36. Misunderstanding as to the eventual costs of a pension system was shared by some union officers as well as rank and file members. Although some unions sought actuarial advice, none of the plans in operation in 1930 was completely drawn up by actuaries. $I d$. at 11 .

15. Id. at 125 . In six of the ten internationals which were paying benefits in 1930 contributions by members had been raised one or more times. Id. at 45 .

16. In one instance, forty per cent of a pension fund was used to help make up for deficiencies in other union funds, and twenty per cent was invested in projects owned and managed by union officers. Id. at 97 . In some instances pension funds may have been used to support strikes. See Dankert, Contemporary Unionisar in trae United States 240 (1948). In general, however, pension funds were managed economically. LATIMER, Trade Union Pension Systems 125 (1932).

17. Minkoff, Trade-Union Welfare Programs in Bureav of Lador Statistics BuzLetiN No. 900, Union Healte and Welfare Plans 11, 12-13 (1947).

18. Latimer, Trade Union Pension Systems 37 (1932).

19. Id. at 38. While it is difficult to generalize concerning the details of these plans, a few similarities are apparent. Benefits promised were small in all cases, ranging from $\$ 60$ to $\$ 840$ per year. Id. at 42 . Moreover, promises sometimes exceeded actual payments. Ibid. Lump sum death payments were ordinarily payable to survivors of active contributors and of retired pensioners. Id. at 42-3. To be eligible for benefits, one generally had 
union disbursements for pensions decreased sharply. $\oplus$ This lack of interest continued until fringe benefits were injected into collective bargaining on a large scale during and after World War II..1

\section{Stimulus of World War II}

The Second World War gave a terrific impetus to the private pension movement and completely changed its character. For unlike earlier plans, which were unilaterally established, plans initiated since 1942 are largely the product of collective bargaining between unions and management. In part, the growth of pensions since 1942 has stemmed from the severe wartime limitations on direct wage increases imposed by the Stabilization Act of 1942. ${ }^{22}$ At the same time, employer contributions to employee health and welfare programs "in a reasonable amount" were specifically exempted from the provisions of the Act. ${ }^{23}$ Unions, unable to persuade the National

to attain a specified age. Id. at 38. Frequently a long period of union membership, varying from twenty to thirty years was also required. Id. at 39 . Six of the ten internationals required a showing of need. These plans granted pensions only if the recipient was ineapable of obtaining sustaining employment. Definitions of "sustaining employment" included both specified minimum monthly earnings and a certain number of days of work per week. Id. at 40-1. Funds to provide benefits came either from international dues or specific pension assessments. Id. at 45 .

20. Old-age disbursements by standard AFL national and international unions during this period were as follows:

$\begin{array}{lr}\text { Year } & \begin{array}{c}\text { Amount } \\ 1927\end{array} \\ 14,348,936 \\ 1928 & 4,712,731 \\ 1929 & 4,883,028 \\ 1930 & 5,910,995 \\ 1931 & 6,090,743 \\ 1932 & 6,148,302 \\ 1933 & 4,678,636 \\ 1934 & 3,912,940 \\ 1935 & 3,684,954 \\ 1936 & 4,784,506 \\ 1937 & 4,600,056 \\ 1938 & 5,334,206 \\ 1939 & 2,073,327\end{array}$

Green, We Work for the Future 64 (1941). See also Bureau of Lacor Statistrcs Bllletin No. 946, Eurployee Benefit Plans Ujder Collective Barganing 2 (1948).

21. But in some instances, unions were "forced" into the welfare field during the thirties in order to compete with company unions which frequently carried on welfare activities. Minkoff, supra note 17, at 13 .

22. 56 STAT. 765 (1942), as amended, 50 U.S.C. $\$ 961$ (1946).

23. 56 Stat. $76 \$$ (1942), 50 U.S.C. $\$ 970$ (1946). As finally interpreted the phrase "reasonable amount" did not constitute a limitation on contributions. The president empowered the Economic Stabilization Director to define "reasonable amount." Exec. Order No. 9250, tit. 6, $\$ 2,3$ Cone Fen. Regs. (Cum. Supp. 1943). Under this grant, the director defined as a reasonable amount "contributions . . . to an employees" trust or under an annuity plan which meets the requirements of section $165(\mathrm{a})$ of the [Internal Revenue] Code. ..." 32 Cone FEd. Regs. \$4001.1(h)(1) (Cum. Supp. 1943). Treasury regulations allowed as "reasonable" any contributions to plans qualifying under Isir. REv. CoDz 
War Labor Board or the Treasury's Salary Stabilization Unit to grant them wage increases, concentrated their attention therefore on "fringe" benefits. And many employers faced with the problem of high labor turnover were willing to initiate pension and other benefit plans in an attempt to keep their working forces intact and to attract additional employees. ${ }^{24}$ In this favorable climate, pension schemes enjoyed a phenomenal growth. ${ }^{25}$

This movement coincided with amendments to the Internal Revenue Code which served to clarify ambiguities in the Code and to publicize the tax advantages of pension programs. ${ }^{26}$ Prior to 1942 , pension devices, where used, frequently were established to minimize taxes and to provide extra compensation to key employees. ${ }^{27}$ If a plan were approved by the Treasury

$\S 165$ (a) regardless of amount. T.D. 5186, $\$ 1002.8,1942-2$ Cum. BuLt. 248, 352, as amended by T.D. 5295, § 1002.8, 1943 Cum. Bulc. 1193, 1197, discussed in Maduro, Somc Corporation Income Tax Problems of Retirement Pension Plans, N.Y. Journal of Commerce, July $15,1943, \S 2$, p. 10, col. 1-3.

24. See Research Institute of America Research Institute Analysis No. 30, Pay Increases Under Wage and Salary Stabilization 30 (1943); Held, HIcallh alld Welfare Funds in the Needle Trades, 1 Industrind \& Labor Red. Rev, 247, 249 (1948).

25. Plans with respect to which favorable rulings for qualification under INT. REv. CoDE $\$ 165$ (a) had been isstued through Aug. 31, 1946 were classified according to the years in which they became effective as follows :*

$\begin{array}{lr}\text { Prior to } 1939 & 622 \\ \text { Jan. 1, 1940-Sept. 1, } 1942 & 843 \\ \text { Sept. 2, 1942-Dec. 31, } 1944 & 4,208 \\ 1945 \text { and 1946 } & 1,189 \\ \text { Includes } 47 \text { plans combining pension and profit-sharing fea- } \\ \text { tures. This compilation excludes a number of plans which were } \\ \text { established in 1945 and 1946, but as to which rulings had not been } \\ \text { issued on Aug. 31, 1946. }\end{array}$

Bureau of Internal Revenue (Income Tax Unit), Pension Tritst Statistical Tables, Table 2.

That wage stabilization policy greatly influenced the growth of pensions is acknowledged by all commentators. See, e.g., Bureau of Labor Statistics Bulletrn No. 946, Earployee Benefit Plans Under Collective Bargaining 2 (1948); Held, supra note 24, at 249-50; Kwasha, Union Interest in Employee Retircment Plans in AmEricaN Management Ass'n Personnel Series No. 118, Trends in EMrployee Healtil and Pension Plans 3, 5-6 (1948). Latimer considers it the most important single factor. Latimer, Social Security in Collective Bargaining in ProceediNGs of NEW YORK UNIversity FIRST ANNUAL CONFERENCE ON LABOR 6-7 (1948). Other commentators attributo even greater importance to the tax stimulus of the 1942 amendments to the Internal Revenue Code, pages 685-6 infra. See Clark, Profit Sharing and Pension Plans (Law and Taxes) 40 (1943); O'Neml, Modern Pension Plans 13 (1947); DeWind, Special Wartime and Other Problems With Respect to Pension and Profit-Sharing Plans Under the Federal Income Tax in Proceenings of NEw York University Thind AnNuar. INSTitute on Federal Taxation 87 (1945).

26. O'Neilt, Modern Pension PunNs (1947); Latimer, supra note 4, at 7.

27. The Treasury Department first called Congress' attention to the possibility of using pension trusts to avoid corporate income taxes in 1937. One of the chief devices was to set up a revocable trust during years when corporate income was high. When, in future years, corporate income declined, the trust principal plus income could be returned 
Department the employer could deduct each year as a business expense not only "reasonable" contributions for currently-accruing liabilities ${ }^{\mathrm{s}}$ but also such additional contributions as the Bureau of Internal Revenue found "reasonable." 29 A pension trust fund could easily qualify for Treasury Department approval if it benefited merely "some or all" of the employees of a particular employer. ${ }^{30}$ Hence an employer could secure substantial tax benefits without actually providing pensions for rank-and-file employees.

Under the 1942 revision, tax advantages still exist but the extreme abuses of the past are no longer possible. The Treasury Department will approve a plan only if it benefits at least fifty-six per cent of all employees except certain classes specifically listed, ${ }^{31}$ or if the Commissioner of Internal Revenue finds that the plan offered for approval does not discriminate in favor of officers, supervisory or highly paid employees, or stockholders. ${ }^{32}$ The new law also specifies in considerable detail how much an employer can deduct

to the corporation. The additional income thus acquired would have minimum tax consequences because the corporation had postponed receipt to a year in which its lower income placed it in a favorable tax bracket. This device was discussed in Hcarings bcforc Joint Committee on Tax Evasion and Azoidance Purstant to Public Res. No. 40, 75th Cong., 1st Sess. 291 (1937). In 1938 Congress provided that no pension trust could be approved if prior to the satisfaction of the fund's liabilities to employees it could be diverted to purposes other than exclusive employee benefits. Revenue Act of $1938, \S 165$, 52 Stat. 518 (1938). The inadequacy of this revision was pointed out in 1942, Hearings before Honse Committee on Ways and 11 cans on Rezenne Revision of 1942, 77th Cong., 2d Sess. 87, 1004-5, 2405-10 (1942).

28. Revenue Act of 1928, $\$ \$ 23(\mathrm{a}),(q), 45$ Stat. 799, 802 (1928); Revenue Act of 1936, §\$23 (a), (p), 49 Stat. 1658, 1661 (1936).

29. The deduction was subject to the limitations that it could not have been talien in previous years and had to be prorated equally over the ten years following the contribution. Revenue Act of 1928, $\$ 23(\mathrm{q}), 45$ STAT. 802 (1928); Revenuc Act of 1936, \$23(p), 49 STAT. 1661 (1934).

Although the statute is broadly worded, presumably the right to deduct contributions in excess of amounts necessary to meet current liabilities was included to enable employers to deduct contributions for pensions covering service rendered before the plan's establishment. See 20 TAxes 432-3 (1942).

30. Revenue Act of 1921, $\$ 219(f), 42$ Stat. 247 (1921); Revenue Act of 1928, $\$ 165$, 45 Stat. 839 (1928).

31. The classes which need not be included in computing the fifty-six per cent coverage are "employees who have been employed not more than a minimum period freseribed by" the plan, not exceeding five years, employees whose customary employment is for not nore than twenty hours in any one week, and employees whose customary employment is for not more than five months in any calendar year. . . " INr. REv. Cone $\$ 165$ (a) (3) (A).

32. INT. REv. CODE $\$ 165(a)(3)(B)$. These requirements have not prevented the approval of plans discriminating against rank and file employees. Discrimination is possible because of at least two inadequacies in the present law. First, only fifty-six per cent of the relatively permanent employees need be included in a pension plan to gain approwl under INT. REv. CODE $\$ 165(a)$, see note 31 stpra, and, second, there need be no requirement that employees have any rights to employers' contributions before reaching retirement age. From these facts it is contended that the employees who primarily benefit from a pension are those with relatively long years of service, high salaries, and positions on a supervisory or executive level. For a discussion of this problem see Rondrss, Isspact 
and still meet the test of reasonableness. ${ }^{33}$ The high excess profits taxes during the war persuaded employers to take a renewed interest in pensions in order to benefit from the tax deductions available under a qualified plan. ${ }^{84}$ And labor leaders, in turn, were stimulated by management activity. ${ }^{36}$

The end of the war caused only a temporary decline in the rate of growth of these pension plans. For a while, pensions occupied only a secondary role in bargaining strategy ${ }^{36}$ as the disappearance of wage controls left unions

of Taxes on Industrial Pension Plans (Industrial Relations Counselors, Industrial Relations Monograph No. 14) 22-6 (1949).

In a letter to the Joint Committee on Labor-Management Relations, the Commissioner of Internal Revenue discussed various methods of integrating private pension plans with the federal social security program. Of the 2,688 pension and profit-sharing plans which were formally integrated at the time of his letter, 735 covered only compensation above a given figure, usually $\$ 3,000$. And 1,299 of the plans provided for a higher benefit rate with respect to compensation above a set figure, usually $\$ 3,000$. The remainder of the integrated plans provided for the deduction of any social security benefits from companyfurnished benefits. Moreover, the Commissioner reported that 3,260 approved plans bencfited primarily higher paid workers by being limited to persons in specified job classificitions which he thought probably included only salaried employees. He concluded with the estimate that between 4,500 and 5,000 plans (about one-half as of August 1946) "either have excluded all hourly wage employees or have benefitted [sic] primarily the higherpaid employees through integration with the social-security program." SEN. REP. No. 986, PART 4, 80th Cong., 2d Sess. 15-16 (1948). But see Note, Tax Consequences of Deferred Compensation Plans, 49 CoL. L. REv. 376, 377 (1949) which takes the unsubstantiated position that discrimination is no longer possible with plans qualifying under INT. REv. CODE § 165(a).

In addition to revising the qualifications necessary for approval under INT. REv. ConE $\$ 165$ (a), the 1942 amenders provided that deductions could be taken for contributions to non-qualified plans only if the employees' rights to such contributions were "non-forfeitable" when made. INT. REv. CODE $\$ 23(p)$ (1) (D). For indications that the non-forfeitability requirement may not be sufficient to prevent tax advantages from accruing to beneficiaries of non-qualified plans see Note, Tax Consequences of Deferred Compensation Plants, 49 CoL. L. REv. 376, 381-2 (1949).

33. InT. Rev. Code $\$ 23(\mathrm{p})(1)(\mathrm{A})$ applies to the deductibility of contributions to a trust qualified under INT. REv. CODE \& 165 (a). INT. REv. CODE $\$ 23$ (p) (1) (B) imposes parallel restrictions on contributions toward the purchase of retirement annuities.

34. One authority estimates that under wartime tax rates each dollar contributed by an employer for pensions, if the plan qualified for deductions, cost the employer only fourteen and a half cents because the balance would have gone to the government in taxes. DeWind, Federal Regulation of Pension Plans in Natronal Industrual Confentence Board Studies in Personnel Policy No. 67, Designing a Conpany Pension Plan 10 (1944). See also RobBins, op. cit. supra note 32, at 49.

35. Latimer, Social Security in Collective Bargaining in Proceedrasgs of New Yokn UnINERsity First AnNual CONFEREnce on LABOR 7 (1948). The author discusses long-term factors which have helped stimulate interest in pension plans since 1940. Id. at 5-9.

36. Even in this period, pensions continued to be a significant union objective. Sec Resolution No. 34, Final Proceedings of the Eightr Constitutional Convention of the CIO 184 (1946) ; Resolution No. 24, Final Proceedings of the Nintu ConstrtUtTonal Convention of tHE CIO 236 (1947). In contrast with the 1946 and 1947 resolutions, sipra, the 1948 statement employs stronger language, urging "that its affiliated 
free to concentrate on direct wage increases postponed during the war years. ${ }^{37}$ This de-emphasis, however, was reversed by the success of the United Mine Workers in securing a pension plan from mine operators. And a series of NLRB rulings and judicial opinions ${ }^{38}$ held that pension and welfare benefits are an appropriate subject for collective bargaining ${ }^{\circ}$ under the

unions embark immediately on a vigorous campaign to secure pension, health, and welfare benefits through collective bargaining." Resolution No. 24, 1945 Procerornas of TIRE Tente Constitutional. Convention of the CiO 333, 334 (1948).

The importance which rank and file members attach to fringe benefits apparently varies. In 1947, for example, Ford workers were asked to choose between a welfare program coupled with a modest wage increase and a larger wage increase without welfare benefits. They overwhelmingly chose the latter. SEN. REP. No. 986, PART 1, 80th Cong., 2d Sess. 41 (1948). See also Weeks, Report From Pittsburgh, New Republic, Oct. 17, 1949, p. 7 at 8.

Two recent surveys shed some light on rank and file preferences. In the first, results were tabulated from 1,339 questionnaires submitted to job applicants. Applieants were asked to list ten stated employment factors in order of their personal preferences. Pensions were not included except by implication in a group designated as "Benefits (Vacation, sicl: pay, insurance, etc.)." The general tabulation showed most applicants ranked "Benefits" as of least importance. There was some variation within different age groups, edueational background, and financial obligations. Applicants for positions involving mechanical work listed "Benefits" ninth in importance. Jurgensen, Selected Foctors IWhich Influcnec Job Preferences, J. Aprifed Psychology 556, 560, Table 3 (1947).

A similar procedure was followed among 300 job applicants in a southern city, and "Benefits" were listed seventh in importance, Thompson \& Goad, What Worlcrs Want From Their Jobs, Employment Security Review, Feb. 1949, pp. 11, 12.

Within the "Benefit" area, according to one survey, desire for pensions is higher than is the desire for other welfare items such as sick leave with pay and life insurance, $W$ hot the Factory Worker Really Thinks, Factory Mranagement \& Mraintenance, Oct. 1949, p. 98.

37. See Resolution No. 38, Final Proceenrngs of the Eighta Constitutroiral Co:iveNTION of the CIO 234, 236 (1946); Resolution No. 7, Final Procendings of tre Ninth Constitutionat Convention of the CIO 221, 222 (1947).

38. Inland Steel Co., 77 N.L.R.B. 1 (1948), enforcement granted, 170 F.2d 247 (7th Cir. 1948), cert. denied, 336 U.S. 960 (1949); W. W. Cross \& Co., 77 N.L.R.E. 1162 (1948) (group health and accident insurance), enforcement granted, 174 F.2d 875 (1st Cir. 1949) ; Tide Water Associated Oil Co., 24 Labor Relations Rereresce AlariunL 1518 (1949) (phrase "retirement of Employees" in management functions clause does not relieve employer of duty to bargain on pension plan).

39. Mianagement efforts to secure congressional action amending the Tait-Hartley" Act specifically to exclude pensions from the sphere of compulsory collective bargaining have thus far been unsuccessful. See Hcarings before Joint Commiltee on the Operations of the Labor-MIanagentent Relations Act, 1977, 80th Cong., 2d Sess. (1948) fassim. The Joint Committee summarized arguments for and against compulsory bargaining on pensions. Sen. REP. No. 986, Part 4, S0th Cong., 2d Sess. 7-9 (1948). For a more complete statement of arguments concerning mandatory bargaining on pensions see Couper, Collective Bargaining on Pensions and Other Employee Bencfit Plans in AzrenrCan Mlanagenient Ass's Personnei Sertes No. 123, Eurployez Bemiefit Platis aiid Collective Bargaining 3, 7-10 (1948). Management's position is presented in detail in National Ass'n of Mianufacturers, Industrial Relations Division, Mfemorandum: Some Major Aspects of Employee Benefit Plans 14-23.

In the 1949 hearings on the proposed Taft-Hartley Act repeal, compulsory bargaining on pensions was not a major question. See Hearings before Commillee on Labor 
Taft-Hartley Act. ${ }^{40}$ Spurred by these successes, other unions pressed for ward with pension plans that have extended their coverage to new indus= tries employing millions of workers.

\section{Collective Bargaining Process}

More general acceptance by management of the responsibility of establishing pension programs marks a significant advance in social thinking. ${ }^{41}$ This agreement in principle, however, still leaves considerable room for management and labor to disagree. Among other things, they fail to see eye to eye about methods of funding and financing the plan, the desirability of requiring the compulsory retirement of workers eligible for benefits, and the optimum size of the bargaining unit in pension negotiations.

\section{Financing}

The extent to which employees should participate in financing retirement programs has become the most controversial issue in current pension negotiations. In the past, neither labor nor management consistently favored or disapproved of the contributory principle. ${ }^{42}$ Today, however, as exemplified

and Public Welfare on S. 249, 81st Cong., 1st Sess. (1949) passim and Hearings before Special Subcommittee of Committce on Education and Labor on H.R. 2032, 81st Cong,, 1st Sess. (1949) passim. Suggestions were made, however, to remove pensions from the sphere of mandatory bargaining. See, e.g., Hearings on H.R. 2032, supra, at 534-5. But even the minority reports filed by members of these committees did not propose eliminating pensions from the sphere of compulsory collective bargaining. See SEN. REP. No. 99, PART 2, 81st Cong., 1st Sess. 52-3, 72 (1949) ; H.R. Rep. No. 317, PART 2, 81st Cong., 1st Sess. 34-5, 36 (1949). Sentiment among many members of the Senate Labor Committee continues to favor mandatory bargaining on pensions. See, $e . g$. . Communication to the Yale Law Journal from the Honorable Elbert D. Thomas, dated Oct. 26, 1949, in Yale Law Library; Communication to the Yale Law Journal from Mary Van Demark, Secretary to the Honorable Claude Pepper, dated Oct. 27, 1949, in Yale Law Library; Communication to the Yale Law Journal from the Honorable Hubert H. Humphrey, dated Oct. 27, 1949, in Yale Law Library.

40. 61 StaT. 136, 29 U.S.C. § 141 (Supp. 1947).

41. See Johnston, Security For Employes Through Retirament Plans-Industry's Activity, N.Y. Journal of Commerce, July 15, 1943, §2, p. 4.

Some observers suggest, however, that acceptance of the welfare principle is less a matter of enlightened social thought than of sound business practice. See Brodie in Pensions and Other Isstes in Collective Bargaining (Panel Session) in AMrRican MANagement Ass's Personnet Series No. 131, Welfare Issues in Collective BatraninING 3, 7-8 (1949) ; Hopkins, LABOR IN THE AMERICAN EconoMy 121-3 (1948); Rowwns, op. cit. supra note 32 , at 48 . And some management pronouncements have lent strength to this view. See, e.g., The Public Stake in the Stecl Dispute, NAM News, Oct. 1, 1949, p. 2.

42. Brodie, supra note 41 , at 8 . For a brief summary of the history of financing arrangements see Lipton, Insured Plans in American Managedent Ass'n Insuinance: Series No. 73, Trends in Retrrement Planning 19 (1948). For a statistical summary see Bureau of Internal Revenue (Income Tax Unit), Pension Trust Statistical Tables, Table 3. For results of a valuable survey covering about thirty per cent of all employees 
by the recent steel dispute, employers regard employee contributions as desirable. In part, this attitude probably stems from a hope that future union demands will tend to be more limited if labor must help pay for them. ${ }^{43}$ Also, many employers are convinced that employee contributions are necessary in order to provide more adequate benefits. ${ }^{4}$ Some even regard the contributory principle as "psychologically necessary" to preserve the virtues of thrift and self-reliance, maintain the dignity of human personality, and avert paternalism. ${ }^{45}$ Labor unions, on the other hand, seek to maximize their gains from the collective bargaining process by insisting on the "basic principle" that pensions be financed solely by management." Moreover, unions insist that non-contributory pensions permit the inclusion of a greater number of employees than a contributory plan ${ }^{47}$ since under some contributory plans workers are not compelled to join.

Labor's attitude finds support in existing tax laws which tend to favor the non-contributory principle. Contributions by an employer to a pension

participating in industrial pension plans at the end of 1947 see BANkers Trust CossPANy, 289 RETIREAIENT Plans 9-10 (1948).

43. See Jamison, supra note 10, at 5; What You Necd to know About Pcnsions, Factory Mranagement \& Mraintenance, Dec. 1949, p. 54, col. 1; N.Y. Times, Oct. 22, 1949 , p. 16, col. 2.

Phrased differently, this contention suggests that employces will better understand the costs of employee benefits if they contribute to their support. See Brower, Cortributory vs. Noncontributory, 11 Mianagearent Recond 286 (1949). Statisties support the belief that workers do not appreciate the cost of pensions. See What the Factory Worker Really Thinks, Factory Mianagement \& MIaintenance, Oct. 1949, p. 98 at 100-101.

44. See NAMI News, Sept. 17, 1949, p. 6; Jamison, supra note 10, at 5; Natro:an. Ass'n of Manufacturers, Industrial Relations Dep't, Imsorsiatio:i Bulleti: No. 7, p. 4 (Re-issued 1949). While the Steel Industry Board recommended the non-contributory principle both for social insurance and pensions, STEEc Iripustry BoArd, REFosr to the Prestoent of the United States on the Lasor Dispute in tre Basic Stere INDUSTRY 66, 79 (1949), it also suggested that through collective bargaining the parties might agree, with respect to social insurance, at least, to employee contributions for benefits requiring funds greater than those which the Board felt industry alone should provide. Id. at 68 .

45. See, e.g., Stateanent of the Colorado Fuel and Iron Corp. Conceritisg rise Econonitc Dearands of the Utited Steelworkers of Axrerica-CIO tefore tae SteEL INDUSTRY BoArd 23-32 (1949), and sources cited therein; PritcretT, THE Soctal Prinosophy of Penstons 10 (1930) (suggesting that the "fabric of our socicty" may" be at stake and foreseeing dire sociological consequences resulting from non-contributory benefit plans). For a more restrained statement of this view in a summary of arguments on both sides of the contributory issue see Alvord, What's New on Employe Contributions, N.Y. Journal of Commerce, Sept. 23, 1948, \$2, p. 18, col. 2.

The Steel Industry Board dismissed this argument with the observation that "[t]bere is no evidence ... that workers in industries where the employer pays all are any less dignified or self-reliant than other workers, or that their employers are more paternalistic." STEEL INDUSTRY BOARD, op. cit. supra note 44, at 68 .

46. See, e.g., UAW-CIO, Collectrve Bargarmang Hastoroor for Worners SECurity Prograxis 11-13 (Revised Oct., 1949).

47. Id. at 26; Murray, Collective Bargaining on Social Sccurity, N.Y. Journal of Commerce, Sept. 23, 1948, $\$ 2$, p. 6, col. 3, 4 . 
program which meets Treasury Department qualifications are deductible as a business expense. ${ }^{48}$ This is not true of an employee's contributions. His payroll deductions are included in his taxable income. ${ }^{49}$ As a result, more insurance can be purchased with a given number of dollars if the employer alone contributes to the pension fund..$^{\text {so }}$

Tax experts have long criticized this different tax treatment of employer and employee contributions. ${ }^{\text {51 }}$ From the standpoint of industrial relations, this anomaly in the tax laws encourages union resistance to the contributory principle even where joint contributions may be the most desirable financing arrangement. And from a tax viewpoint, an employee's contributions to a retirement program required by his employment relationship need not be regarded as income constructively received. ${ }^{.2}$ This doctrine of constructive receipt is intended primarily to forestall tax avoidance. It is ordinarily in. voked where a taxpayer with a high income attempts to bring himself within a low income bracket by transferring the right to receive part of his income to someone else while he continues to enjoy benefits from it. Therefore it should not be applied to rank-and-file wage earners who contribute to qualified retirement programs. ${ }^{53}$

48. See pages $684-6$ and note 33 sispra.

49. The Code specifically requires that amounts withheld for social security may not be deducted in computing an employee's taxable income, INT. REV. CODE $\$ 1402$; nor may amounts withheld under the Railroad Retirement Act be deducted. INT. Rev. Cone $\$ 1503$.

In two rulings, the Treasury Department held that amounts withheld from employee salaries for private pensions were taxable income to the employee. I.T. 2874, XIV-1 Cuns. Burl. 49 (1935); and I.T. 2891, XIV-1 Cunr. Burr. 50 (1935). This viewpoint was affirmed in Renton K. Brodie, 1 T.C. 275 (1942) (annuitics purchased by employer as bonus to employees taxable to employees in year bonus is earned).

Even earlier, the Treasury Department had held that contributions required of civil service employees should be reported for income tax purposes. T.D. 3112, 23 TrEeAs. Dec. INT. Rev. 1 (1921). This ruling was sustained in Cecil W. Taylor, 2 T.C. 267 (1943).

50. See, e.g., Steer Industry Board, op. cit. supra note 44, at 67 . Various cstimates have been made of the amount of retirement income purchasable with the employce's taxable dollar. See, e.g., Gardner \& Weber, Trusteed Plans in American Managenens Ass'N Insurance Series No. 73, Trends in Retirement Planning 7, 11 (1948). A moro recent estimate finds that an employer has to pay sixty cents for a dollar's worth of retirement income, but an employee, whose contributions are not tax deductible, has to pay a dollar for eighty cent's worth. Couper, What Next in Company Pcusion Plans, 11 MANAGENENT ReCORD 4 (1949). Percentage-wise, the employer's contribution will buy twenty per cent more benefits. UAW-CIO, Collective Bargaining HANDbook roR Workers Security Prograxis 26 (Revised Oct., 1949). Both Great Britain and Canada have provisions exempting employee contributions to pension plans from personal income taxes. Couper, sipra, at 4.

51. See Note, Griswold, The Tax Treatment of Employees Contributions to Pcision Plans, 57 Harv. L. Rev. 247 (1943) ; RoBbiNs, op. cit. silpra note 32, at 32-44.

52. Id. at 64 ; Note, supra note 51 , at 249.

53. Where contributing to the plan is a condition of employment it would appear inequitable not to permit the employee to deduct his contributions in view of the fact that no tax avoidance is intended. Extending this principle to social security, there is no 


\section{Method of Funding}

The increasing use of pension programs has provoked a heated controversy between banks and insurance companies ${ }^{54}$ over the comparative merits of pension trusts ${ }^{55}$ and group annuity policies ${ }^{5 s}$ as funding devices. ${ }^{57}$

reason for not allowing the employee to deduct his payroll tax. A better argument can be made for disallowance where the plan is voluntary since the employee has full control over the income which he allots to pensions. See Rosbins, op. cit. silpra note 32, at 36-7, 43,64 . But even in this case taxation of these contributions might well be delayed, for purposes of administrative convenience, until received in the form of pension benefits. Id. at 43 , 64,65 ; see also Note, supra note 51 , at 250 .

54. For an account of some of the tactics in this rivalry see Mrooney, Competition Keen in Pensions Field, N.Y. Times, July 11, 1949, p. 26, col. 1. Intervicws with officials of several leading trust and insurance companies located in Nev York City indicate that in general neither banks nor insurance companies participate in the actual negotiations between unions and management, though at least one bank has participated in these negotiations in an advisory capacity. Both banks and insurance companies prefer to leave the bargaining itself to the immediate parties, assisted in some cases by private actuaries. They have, however, entered into preparations preceding the collective bargaining. Thus, when asked to do so by management, insurance companies ordinarily outline and prepare cost estimates of one or more possible plans. And banks, in the course of providing services to their actual or potential customers, have given information regarding the types of pians currently popular and the various methods of funding available. As trustee, a bank is supposediy a nettral party, and refrains from taling part in any negotiations leading to the choice of itself as trustee.

55. There is some confusion of terminology in this field. Pension trust agreement, as here used, refers to the general arrangement whereby funds are turned over to 3 trustee, frequently a bank or trust company, for investment and management in accordance with such directions as the employer and/or employees give in the trust agreement. The trustee also undertakes to pay benefits according to the terms of the pension plan and trust agreement. If part of the trust funds are invested in annuity contracts, the trust is usually designated as "partially insured."

The following table indicates the comparative increased use of the pension trust device in recent years.

\begin{tabular}{ccc}
\multicolumn{3}{c}{ Estmated Number of Pension Plins } \\
Adopted During & Trustecd & Group Anmuitics \\
1941 & 50 & 200 \\
1942 & 50 & 100 \\
1943 & 100 & 150 \\
1944 & 200 & 200 \\
1945 & 300 & 150 \\
1946 & 250 & 150
\end{tabular}

Kwasha, supra note 25, at 5 (Reprinted by permission).

Mieasured by number of employees covered, there is an even stronger trend toward the use of trusteed plans. Ibid. The tendency for large plans to be funded by pension trusts is shown in the following table.

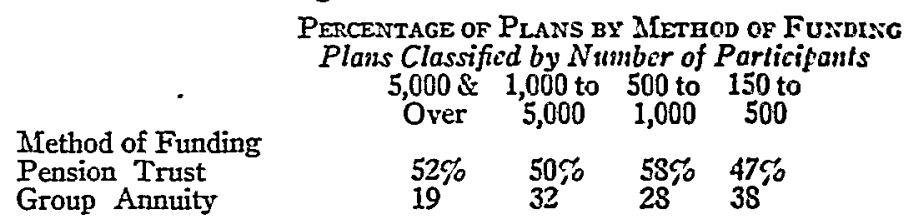

Bankers Trust Codrany, 289 Retirentent Plans 12 (1948).

56. Group annuities and pension trusts are the most common methods of funding pen- 
Thus, trustee banks argue that pension trusts are more flexible and adaptable than group annuities to the needs of a particular group. ${ }^{5 S}$ For example, permanent and total disability benefits cannot ordinarily be included in a group annuity policy. ${ }^{59}$ On the other hand, where trust funds are employed, the parties can include whatever disability provisions they wish, ${ }^{60}$ or pay to and withdraw from the trust according to the terms of any legal agreement worked out between them. ${ }^{61}$ Moreover, banks insist that the use by insurance companies of overly conservative mortality and interest estimates ${ }^{02}$

sion programs. Annuity policies are issued subject to insurance company underwriting rules. For a summary of these rules see O'Nerl, Modern PENsion PluNs 128-30 (1947). Policies ordinarily cover groups numbering fifty or more persons. In some cases, groups of twenty-five are insurable. Brower, Funding $A$ Pension Plan, 11 MLANAGEMENT RECORD 466, 467 (1949). The forms and types of policies offered by most insurance companies are similar. For description see O'Nerts, op. cit. supra, at 112-14. This comparative standardization limits the applicability of group annuities.

57. Two other important devices are the individual annuity policy plan, discussed in O'Neill, Modern Penston Plans c. VII (1947); and the group permanent contract, discussed $i d$. at 231-2; and in St. John, Financing a Pension Plan in HANDnook Fon PENsion Planning 83, 116-128 (1949). Less important arrangements include group deposit administration, discussed in Blagden, Flexibility Plus Insurance Company Guarantecs, N.Y. Journal of Commerce, June 16, 1947, § 2, p. 23, col. 1; and various combinations of insured and trusteed funding, such as ordinary life pension trusts, discussed in St. John, supra, at 133-7. For a convenient tabular comparison of important elements of these funding methods see $i d$. at $142-3$.

For general discussions of funding methods see O'NenLe, op. cit. supra, c. XI; St. John, supra, c. 4 ; Brower, Funding A Pension Plan, 11 Managenenr Record 466 (1049); Hamilton, Employee Benefit Plans, 83 Trusts \& Estates 583 (1946); Kirsch, Financing Plans by Instred Methods, 85 Trusts \& Estates 214 (1946); McConnel, Financing Plan Through Trust Fund, 85 Trusts \& EsTates 210 (1947); discussions in N.Y. Journal of Commerce, July $15,1943, \S 2$.

58. See Gardner \& Weber, Trust Fund or Groutp Anmuity, 84 Trusts \& Estures 45 (1947) ; Buck, Self-Administered Trusteed Plans, N.Y. Journal of Commerce, July 15, 1943, § 2, p. 20, col. 3.

59. St. John, supra note 57, at 140; National Industrial Conference Board Studies in Personnel Policy No. 61, Trends in Company Pension Plans 33 (1944).

60. St. John, silpra note 57, at 140.

61. A claimed advantage of the trust is that the employer can vary his contributions from year to year according to his financial condition. Brower, Finding $A$ Pcusion Plan, 11 Management Record 466, 467 (1949). Hamilton, while pointing this out, urges that such a practice would be undesirable if the employer fell very far behind in his contributions. Hamilton, Employee Benefit Plans, 83 Trusts \& EsTstes 583, 584 (1946).

62. See, e.g., Gardner \& Weber, Trust Fund or Grontp Anmuity, 84 Trusts \& EsTATES 45,49 (1947). Upon closer analysis, the argument that insurance companies use unnecessarily conservative mortality assumptions appears to be irrelevant to the question of cost over the entire history of the plan. Of a given group of employecs, life expectancy will be unaffected by the funding method chosen. If the benefits promised are to be provided, generous mortality assumptions will require later correction and too conservative assumptions will result in a refund. See Forster, The Methods of Funding Retirement Plans, N.Y. Journal of Commerce, July 15, 1943, \&2, p. 16, col. 4.

Forster also concludes that gross interest earnings will be about the same for group annuities and large pension trusts except to the extent that a trustce invests in 
makes pension trusts cheaper than group annuity policies. ${ }^{68}$ Finally, they urge that administrative charges should be determined by the experience of each particular retirement program and not by the general experience of a large insurance company. ${ }^{64}$

Insurance companies retaliate in kind. They insist that the long term nature of the obligations involved in a pension plan requires great care if the retirement program is to remain financially sound. They remember the losses resulting from annuity operations during the 1930's ${ }^{\text {os }}$ because of unexpected declines in the rate of return on their investment, and unanticipated

sound securities which yield a higher return than is ordinarily available to insurance companies. Id. at $17, \operatorname{col} 2$.

63. See, e.g., Gardner \& Weber, Trust Fund or Group Anmuily, 84 Trusts \& EsTATES 45, 49-50 (1947).

But like claims are made for insured plans. National Industrar Corference Board Studies in Personnel Policy No. 61, Trends un Cosmamy Penision Plars 39 (1944).

64. Guaranty Trust Coarpany, Pension Plan Fundaremitals 16 (1948). In answer to this argument insurance companies point out that standardization of forms and administrative procedure may result in administrative savings not realized by trusteed plans. Hamilton, Employee Benefit Plans, 83 Trusts \& Estates 583, 584 (1946).

Insurance companies include administrative expenses in an all-inclusive "loading fee," frequently $8 \%$ of the premium. This loading fee includes commissions, expenses for actuarial and administrative services furnished by the insurance company, estimated future expenses in connection with payment of benefits, and an amount sufficient to cover any fluctuations in mortality or interest rates. O'Nem, Ḿoders PE:ssios Prass 127 (1947).

Where a state premium tax is payable, trust plans enjoy a corresponding advantage. Hamilton, sipra, at 584; Forster, sipra note 62, at 29, col. 1 .

In addition, if an insured employee withdraws from the plan, there is a surrender of $4 \%$ of the premiums paid. This practice has been frequently criticized. See, c.g., Gardner \& Weber, Trust Fund or Group Ammity, 84 TRUsts \& Estates 45, 49 (1947). With pension trusts, some discount for withdrawals is possible in advance. Hamilton, supro, at 585 .

The administrative expenses of a pension trust can be grouped according to whether they originate within the company itself, are trustees' fees, or are fees for actuarial and legal services.

Among the first group are installation expenses, routine record and bookkeeping expenses, and general administrative expenses including pension committee costs, revisions, and labor and public relations expenses. Although these are also present to 3 certain extent with insured plans, installation and general administrative expenses will usually be included in the loading fee. See Forster, supra note 62, at 29, col. 1 .

An example of trustee's fees is: $1 / 2$ of 1 per cent on first $\$ 500,000$ of principal, $1 / 4$ of 1 per cent on the next $\$ 1,000,000$, J/8 of 1 per cent on the next $\$ 3,000,000$, and $1 / 10$ of 1 per cent on all the remaining principal. MicConnel, Financing Plan Througl Trust Fund, 85 Trusts \& Estates 210, 213 (1947).

Actuarial and legal fees, of course, vary with the amount of service rendered. Either or both may also occur with insured plans. On the services rendered by actuaries see Goldstein, Role of the Professional Employe Benefit Plan Consultant, N.Y. Journal of Commerce, June 16, 1947, \$2, p. 20, col. 1; and Denker, The Role of the Consullant, N.Y. Journal of Commerce, July 15, 1943, §2, p. 35, col. 1 .

65. O'NeILl, Modern Pension Plans 72 (1947). The author suggests that insurance 
increases in life expectancy. ${ }^{66}$ Only an insured plan, they point out, offers a maximum amount of security. Trustees, for example, are under no obligation to make good from their own assets if mortality rates are overestimated or anticipated interest earnings fail to materialize. ${ }^{67}$ If the trust fund proves inadequate, the parties to the pension scheme must either increase contributions or decrease benefits. Insurance companies, on the other hand, are under a contractual obligation to furnish the agreed annuities at the set price. ${ }^{68}$

Collective bargaining on pensions has affected this rivalry. Unions generally prefer plans funded by pension trusts, emphasizing their greater adaptability. ${ }^{69}$ Some unions, mindful of past attempts to weaken unions by use of pension promises, ${ }^{70}$ feel that they can play a greater role in the administration of a plan if it is funded by a trust. ${ }^{71}$ Moreover, individual union members are more likely to credit benefits to union leadership where the union exercises an active role in the administration of the plan.

companies have probably not yet absorbed the losses resulting from annuity contracts concluded in 1930-40. Ibid.

66. For a discussion of the problem of predicting mortality and interest rates and the effect of these rates on pension costs see Calvert, Interest and Mortality Factors in Pension Planning, N.Y. Journal of Commerce, Sept. 23, 1948, § 2, p. 11, col. 1; and Drake, Group Annuity Cost Assumptions and Actual Costs, N.Y. Journal of Commerce, Sept. 23, 1948, §2, p. 12, col. 1. See also Sharp, The Basic Importance of Sontd Actuarial Direction, N.Y. Journal of Commerce, June 16, 1947, §2, p. 19, col. 1.

67. A typical trust agreement might provide that "[t]he Corporation shall pay to the Trustee ... the contributions of employees participating in the Plan, and ... the Corporation's contribution... . All such payments and the accruals thereto from time to time held by the Trustee shall be hereinafter referred to as the 'Fund, . . . ." "The sole responsibilities of the Trustee hereunder shall be to hold and to invest and reinvest from time to time the Fund ... in accordance with the powers and subject to the restrictions stated in this indenture or in any modification or amendment hereof, and to pay moneys therefrom to or for the account of the Retirement Plan Committee for the use of the Plan, and if the Retirement Plan Committee shall so direct, to participants, to annuitants, to joint annuitants, and to beneficiaries under the Plan, in the amounts and as directed by the Retirement Plan Committee upon orders to the Trustce signed by the Retirement Plan Committee from time to time." Bureau of Natronal Afrairs, Handbook for Penston Pianning 331-2 (1949).

68. See, e.g., National Industrial Conference Board Studies in Personned Policy No. 61, Trends in Company Pension Plans 40-1 (1944).

69. See AFL Research Report, Aug., 1949, p. [5] ; UAW-CIO, Collective BArgaining Handbook for Workers Security Programs 22, 27-8 (Revised Oct., 1949); Communications to the Yale Law JourNal from Sam B. Berrong, Executive Vice-President, Amalgamated Ass'n of Street, Electric Railway and Motor Coach Employees of America, dated Oct. 28, 1949, in Yale Law Library, and from Lincoln Fairley, Rescarch Dircctor, International Longshoremen's and Warehousemen's Union, dated Nov, 1, 1949, in Yale Law Library.

70. See page 679 supra.

71. UAW-CIO, Collective Bargaining Handbook for Workers Security ProGRAMrs 27-8, 19-20 (Revised Oct., 1949). 


\section{Compulsory Retirement}

Labor and management sometimes differ sharply over whether the pension program should require the retirement of employees who qualify for pension benefits under the plan. ${ }^{72}$ Unions insist that an employee must consent to his retirement. ${ }^{73}$ Arguing on a doctrinal level, unions contend that seniority rights are designed to protect an employee from being laid off without his consent, as long as others having fewer years of service remain on the payroll. ${ }^{74}$ These rights, unions argue, should protect the employee whether the layoff results from lack of sufficient work or from superannuation. ${ }^{75}$ To this, management answers that the right to retire employees is an essential part of a loosely defined group of functions called "management rights." 76

In reality the dispute arises because labor and management hold different conceptions of the purposes of a pension system. To constitute a legitimate business expense from management's point of view, contributions to a pension system must result in definite benefits to the business. $\pi$ These benefits

72. Almost without exception, unions, in response to questionnaires circulated in preparation of this Comment, answered that pension plans should not require retirement at a stated age. Management took the opposite view with equal vigor. These letters are in the Yale Law Library.

73. See, e.g., the interesting colloquy between union and management negotiators which took place after certiorari had been denied in Inland Sted Co. v. NLRB, 170 F2d 247 (7th Cir. 1948), cert. denied, 336 U.S. 960 (1949), reported in Harding, Negolialing Enployee Pension Plans, 88 Trusts \& Estates 420, $422-4$ (1949).

74. The Inland Steel litigation arose from a related fact situation-refusal by the company to discuss with the United Steelworkers of America the company policy of requiring retirement, with pension benefits, at age sixty-five. See Inland Steel Co. v. NLRB, 170 F.2d 247, 250 (7th Cir. 1948), cert. denied, 336 U.S. 960 (1949). Before the seventh circuit, counsel for the NLRB successfully argued that for purposes of collective bargaining as defined by the Iabor Mranagement Relations Act, 61 Srıт. 136, 29 U.S.C. $\$ 141$ (Supp. 1947), there was no difference between compulsory retirement and discharge for other causes. See Brief for NLRB, pp. 85-9, Inland Steel Co. v. NLRB, supra. For a summary of current seniority clauses and a few of the problems raised by them see Collective Bargaining-Layoff Practices Part I, AFL Rescarch Report, Aray, 1949, p. [3]; and Lay'off Practices in Collective Bargaining Part II, AFL Research Report, June, 1949, p. [3].

75. This was argued successfully in Machinists Union v. General Electric Co., 24 Labor Retations Reference Mfandal 2527 (Ohio Court of Common Pleas, Sept. 27, 1949) (dismissal for old age not good cause under contract permitting termination of employment by discharge for cause only or by voluntary withdrawal).

76. See, e.g., Winans, Benefit Plans Under Collective Bargaining-Problems ard Prospects in Adrertcan Mianagearent Ass'n Personner Serres No. 123, Eurployez Benertr Plans and Collective Barganning 13, 18-19 (1948); Who's Going to Manage -Yort or the Union, Factory Mianagement \& Miaintenance, Aug. 1949, p. 103, col. 1.

77. See Iserman, Welfare Funds in Collective Bargaining in Nutro:sax Ixoustrunt Confreence Board Studies in Busness Econosics No. 8, Union Henlti arid WezFARE Funds 9, 13 (1947). For a discussion of the rights of stockholders to challenge corporate contributions to a pension scheme as an illegitimate business expense see O'Neal, Stockholder Attacks on Corporate Pension Systems, 2 Varv. L. REv. 351 (1949); Note, Legality of Private Pension Plans, 20 NEB. L. REv. 53, 54-5 (1941). 
are ordinarily realized when a retirement program facilitates the removal of superannuated employees from the payroll. ${ }^{78}$ Hence, any provision giving employees control over the time of their retirement might frustrate the aims of the program. Labor, however, views pensions chiefly as part of an over-all plan designed to afford old-age security. ${ }^{79}$ If, because of high living costs and inadequate pensions and social security benefits, an employce finds it desirable to continue working, he should be permitted to do so. ${ }^{80}$

With these views in pointed conflict, it is likely that the bargaining strength of the two parties will determine the issue of compulsory retirement. A more rational solution, however, would require consideration of several factors not ordinarily of controlling significance in the bargaining process. There is no arbitrary age, for example, which marks the beginning of physiological and mental decline in all persons. ${ }^{81}$ Nor do all jobs require the same degree of mental alertness and physical stamina.82 Moreover, many doctors and psychologists seriously question the wisdom of abrupt changes from an active life and familiar environment to a life of comparative inactivity. ${ }^{83}$ Similarly, from society's point of view, the desirability of compulsory retirement is equally uncertain. Experts have long prophesied

78. O'Neint, Modern Pension Plans 102 (1947); Brower, Should Retircment Bc Compulsory, 10 Management Record 72, 73 (1948). For a different view on the economies of compulsory retirement see Harding, supra note 73, at 422; P-H PENS1ON \& PkofTT Sharing Report, Jan. 13, 1950, p. 2.

For a concise statement of management's position see Huppeler \& Ardison, The Question of Compulsory Retirement, N.Y. Journal of Commerce, June 16, 1947, § 2, p. 22, col. 1 .

79. See UAW-CiO, Collective Bargaining Handeook for Workers Secunity Prograsis 3-5 (Revised Oct., 1949).

80. In the depression years of the 1930 's, however, unions adopted a contrary view. Unions then favored compulsory retirement of older workers in order to make more jobs available to new members of the labor force and provide some income to a greater number of individuals.

81. Lawton, When Should A Man Retire 9, N.Y. Times Magazine, April 27, 1947, p. 12 at 52, col. 3; McFarland, The Older Worker in Industry, 21 HARv. BuS. Rev. 505, 509 (1943) ; Miles, The Psychological Aspects of Aging in Problems of Ageing-Brologicat AND Medical Aspecrs 756, 760, 764-66 (Cowdry ed. 1942).

82. See, for example, the recommendations made for assigning older workcrs to jobs for which their capacities are more suited. McFarland, supra note 81, at 518-20. One drawback, of course, is the fact that older workers may adapt less readily to changed techniques and working conditions. See Viteles, Industrual Psycrrology 602-604 (1932).

83. See Carred, Man The Unknown 184-6 (1935); Kardiner, Psychological Factors IN OLd AGE cited in Hochhauser, Work Therapy, Interests, and Activitics in New Goals for Old AGe 114 (Lawton ed. 1943); Lawton, supra note 81, at p. 12, col. 2,3 .

For some light on worker attitude toward compulsory retirement at a given age, sce What the Factory Worker Really Thinks, Factory Management \& Maintenance, Oct. 1949, p. 101. Interviews of 1,200 workers eligible for retirement in one California area indicated that most felt they couldn't afford to retire, but wouldn't want to do so even if they could. Corson, The Old-Age and Survivors Instrance Program in WAR AND 
an increasingly older population for the United States. By 1980 there will be twenty-five people over sixty-five for every hundred between fifteen and sixty-five. ${ }^{84}$ Widespread adoption of the principle of fixed and compulsory retirement will tend to eliminate an ever-increasing portion of the population from the labor force ${ }^{85}$ and thus throw on the working members of the economy the increasingly difficult task of producing for the aged. ${ }^{\mathrm{ES}}$

\section{Bargaining Unit}

In all cases where group annuities or pension trusts are employed it is desirable to include as large a number of persons as possible vithin the coverage of a plan. ${ }^{87}$ Experience has demonstrated the unreliability of mortality predictions for small groups. Consequently, insurance companies will not issue group annuity policies covering groups of less than fifty per-

Post-War Soctal SecurtTy 62 (Cohen ed. 1942). In all the United States, twenty-seven per cent of those over age sixty-five are currently working. Couper, Prescut-Day Pcnsion Problems, 11 Mranagearent Recond 4, 5 (1949). Obviously, the size of the pension influences employee attitude toward retirement. See Lipton, supra note 42, at 20-21.

84. Siestnger, Next Step Forward 47 (1938). For a more comprehensive study of American population see Whezpton, Forecasts of the Population of tae Uiated StATES, 1945-1975 (1947).

85. Present social security legislation in effect requires the insured to retire in order to receive benefits, since no payments are made to persons earning \$15 or more per month. 53 STAT. 1367 (1939), 42 U.S.C. $\$ 403$ (d) (1) (1946). This provision has been attacled on the ground that social security should be used to encourage later, not earlier, retirement. See Sitchter, Soctal Security After the War 22 (1943); Setr. Doc No. 208, 80th Cong., 2d Sess. 42-3 (1949). The Advisory Council on Social Security recommended that no wage test should be imposed on persons aged seventy or over. For those at a lower age, the Council recommended that benefits to which a beneficiary and his dependents are entitled should be suspended for any month during which the bencficiary had earnings in excess of $\$ 35$. But a quarterly accounting would entitle him to any difference between the amount by which his suspended benefits exceed earnings over $\$ 35$ per month. Id. at $42-4$.

86. Councrl of Econosuc Advisors, Business and Governarent 22 (Fourth Annual Report to the President, 1949); N.Y. Herald-Tribune, Jan. 4, 1950, p. 22, col. 1.

Several compromises for extending the period of employment have been suggested. They vary from proposals to extend normal retirement age beyond sixty-five to suggestions that an employee's physical fitness to continue work be determined either by a company or outside physician. See Harding, stpra note 73, at 422 (1949); Pensions and Other Issues in Collective Bargaining in Adrerican Managenent Ass'N Persominec Sentes No. 131, Welfare Issues in Collective Bargainna 3, 9 (1949). The Ford contract fises normal retirement at age sisty-five, but provides that the employee may continue worling with the company's consent until age sixty-eight, P-H Pensiox \& Profrr Sranrio Serv. I 1034, $\$ 9$ (1947). Compare this with a suggested "ideal" arrangement, Lawton, ruspro note 81 , at p. 54 , col. 3,4 .

87. Individual annuity policies may be purchased for members of small groups. These individual annuity contracts offer broader protection than group annuity policies, but their higher cost is sometimes regarded as a disadvantage. See O'NerL, Mropens Pe:sion: Pians 158 (1947); National Industrial Conference Board Studies mi Persoinzer Policy No. 61, Trends in Conipany Pension Plans 42 (1944). 
sons. ${ }^{83}$ And group size of plans funded by use of a pension trust tends to be even larger. ${ }^{89}$ As a result, bargaining on pensions between a single employer or production unit and a single union is sometimes an unsatisfactory and uneconomical procedure.

This emphasis on large group size often makes multiple unit bargaining advantageous. Where the union represents employees in several different units of the same business organization, finding a proper group size is relatively simple. But where the union represents all workers in an industry composed of many small units or many entrepreneurs who enter and leave on short notice, local and regional bargaining may be a practical solution. For example, the development of employee benefit programs in the building and construction industry had to await the formation of employer associations having authority to bind all members of the association..$^{00}$ And in the needle trades, where many enterprises are extremely short-lived, local and regional agreements have been worked out whereby all employers within a given area contribute to central funds from which benefits are paid. ${ }^{91}$ Therefore, as demands for pensions mount, the instances where one union bargains with several employers may increase-and at a time when government action to limit this tendency is being urged..$^{92}$

At the same time, a given employer might find it equally impractical to bargain on pensions with several unions. Employers have long been accustomed to negotiating different wage scales with different unions. But pensions cannot be readily treated in this fashion. They arelong-rangecommitments involving consideration of numerous federal and state laws, the possibility of stockholder objections, and the ability of the company to undertake very substantial obligations. Hence it is highly advantageous for a

88. See note 56 sippra.

89. Through Aug. 31, 1946, favorable rulings under IsT. Rev. CoDE \$165(a) had been issued with respect to 658 self-insured pension plans. In these plans, $1,908,111 \mathrm{~cm}$ ployees participated, an average of approximately 2,900 per plan. Corresponding figures for plans wholly insured by group anntity contracts are: plans, 1,476 ; participating employees, 889,184; average employees per plan, 602. Bureau of INTERNAL Revenue (Income Tax Unit), Pension Trust Statistical Tables, compiled from Table 4.

90. Latimer, Social Security in Collective Bargaining in Proceedings of NEw Yonk University First Annual Conference on Labor 6 (1948).

91. In such an industry, membership in a union is likely to be the most permanent common factor among workers. Because of this, pooled vacation funds were established in the needle trades in 1938. Employers contributed to a central fund from which vacation benefits were paid to union members. The idea soon spread to include health and retirement benefits. See Held, supra note 24, at 248-9.

92. The amount of literature on multi-unit bargaining is increasing rapidly. See, generally, Proceedings of the Conference on Industry-Wide Collective Bargaining (Wharton School of Finance and Commerce) (1949) ; LevY, Multi-EMPLoyer BARGAINing and the Anti-Trust Laws (1949); Freidin, The Taft-Hartlex Act and MultiEMployer Bargaining (1948); Poliak, Soctal Implications of Industry-Wide BarGAINING (1948). 
business to be able to plan retirement programs for the enterprise as a whole rather than for each of numerous bargaining agents. ${ }^{93}$

These practical difficulties have failed to persuade the courts that pensions are not an appropriate subject for collective bargaining. ${ }^{94}$ They do, however, call for different techniques in the bargaining process. For example, the possibility of greater cooperation among union leaders holding collective bargaining contracts with a single employer has already been recognized by some labor leaders. ${ }^{95}$ But how far labor is willing to go in this direction remains unknown. ${ }^{96}$

\section{Federal Control}

Prior to 1947 , the Federal Government exercised no direct control over union-management pension systems. ${ }^{97}$ Section 302 (a) of the Taft-Hartley law, ${ }^{98}$ however, prohibits the payment, by an employer, of anything of

93. Difficulties in multi-union bargaining arise not only in getting various unions to agree on a plan, but also in setting up a system of administration satisfactory to all. See dissent of Member Gray, Inland Steel Co., 77 N.L.R.B. 1, 18-19 (1948), cnforcement granted, Inland Steel Co. v. NLRB, 170 F.2d 247 (7th Cir. 1948), cerl. denied, 336 U.S. 960 (1949); Brief for Trial Examiner on Behalf of Respondent, pp. 36-9, Tide Water Assoc. Oil Co., NLRB Case No. 2-C-6907 (2d Region 1948) ; Hearings before Joint Com:mittee on Labor-11anagenent Relations, S0th Cong., 2d Sess. (1948) passim.

94. See Inland Steel Co. v. NLRB, 170 F.2d 247, 249, 250 (7th Cir. 1948), ccrt. denicd, 336 U.S. 960 (1949); Tide Water Assoc. Oil Co., 24 Labor Relations Rerene:ice MLANUAL 1518-9 (1949).

95. See the suggestion that all AFL unions representing employees of one employer join in presenting uniform welfare demands, Collective Bargaining-Welfare Plans, AFL Research Report, MIarch, 1949, p. [4].

96. Management has often expressed the belief that unions will not be willing to accept a plan negotiated by their rivals. See sources cited note 93 supra. The dispute at the Aluminum Company of America in the fall of 1949, where a CIO union would not agree to a pension program on terms similar to those accepted by an AFL union, lends color to this belief. N.Y. Times, Nov. 17, 1949, p. 3, col. 5; N.X. Times, Nov. 18, 1949, p. 25, col. 2.

Bargaining with a multi-union group has never been successful except for one reported instance in the railroad industry. See Latimer, supra note 90 , at 38.

97. Although there was no direct federal control of pensions prior to 1947, federal law touched the subject in a number of important ways. First, of course, were the tax laws. See pages 684-6 supra. Under certain circumstances certificates issued by a pension plan may also be deemed securities within the meaning of the Securities Act of 1933, 48 Stat. 74 (1933), as amended, 15 U.S.C. $\$ 77 a(1946)$ and therefore subject to its disclosure requirements. See Note, Pcusion Plans as Securities, 96 U. of P^. L. KEv. 549 (1948). Pension contributions are deemed wages for the purposes of the social security excise taxes unless certain requirements set forth in INr. REv. Cop\& $\$ 1426(a)(2)$; and INT. REv. CoDE $\S 1607$ (b) (2) are met. Until it was amended by Pub. L. No. 393, 81st Cong., Ist Sess. $\$ 7$ (d) (4) (Oct. 26, 1949), the overtime provision of the Fair Labor Standards Act, 52 Stat. 1060 (1938), as amended, Pub. L. No. 393, 8ist Cong., 1st Sess. (Oct. 26, 1949), required that under certain circumstances employers' pension contributions be considered as a part of the base for overtime.wages.

98. 61 STAT. 136, 29 U.S.C. \$141 (Supp. 1947). 
value "to any representative of his employees. . . ." Section 302(c)(5) establishes an exception in favor of payments to union pension and welfare funds which meet specified requirements of purpose and administration. ${ }^{09}$ These controls were enacted in the belief that legislation was necessary to guard against the misuse of funds contributed by employers for employee benefits. ${ }^{100}$ The results of almost three years' experience with the Act and the subsequent growth of funds call for a reconsideration of whether a need for government regulation exists, and, if so, whether existing provisions of the law fulfill it.

\section{- Administration of Funds}

To conform with the standards of Section 302(c)(5) an employer must be equally represented with the union in the administration of any union funds to which he makes contributions. Supporters of this provision argued that these contributions were, in effect, compensation for services rendered, and that their enjoyment by the employee ought to be assured. They maintained that the presence of employer representatives was necessary in order to guard against the diversion of funds from purposes other than employee

99. Contributions are permitted for the purpose of financing "medical or hospital carc, pensions on retirement or death of employees, compensation for injuries or illness resulting from occupational activity or insurance to provide any of the foregoing, or unemployment benefits or life insurance, disability and sickness insurance, or accident insurance. . ." 61 StaT. 157-8 (1947), 29 U.S.C. \$186(c) (5) (A) (Supp. 1947).

100. See Sen. Rep. No. 105, 80th Cong., 1st Sess. 52 (1947) ; H.R. Rep. No. 317, PART 2, 81st Cong., 1st Sess. 34 (1949).

The controls in the Taft-Hartley Act, 61 Srat. 136 (1947), 29 U.S.C. $\$ 141$ (Supp. 1947) have an interesting legislative history. Their controversial nature is perhaps indicated by the fact that they had never been included, in their present form, in the majority report of any committee which studied the problem prior to the passage of the TaftHartley Act. They first appeared as an amendment offered from the floor of the Senate by Senator Byrd, 92 Cong. Rec. 4809 (1946), to the Case Labor Disputes Bill, H.R. 4908, 79th Cong., 2d Sess. (1946), which was vetoed by the president, 92 CoNG. Rec. 6674 (1946). As the bill dealt primarily with the settlement of disputes, it does not appear from the committee reports that welfare funds were ever discussed in committce. See SEN. REp. No. 1177, 79th Cong., 2d Sess. (1946) passim; H.R. REp. No. 1493, 79th Cong., 2d Sess. (1946) passim. The floor debates indicate that the major purpose of the amendment was to induce a settlement in the 1946 coal dispute. 92 CoNG. REC. 4891-900, 5041-4 (1946).

When labor legislation revision was being considered in 1947, the House Committee on Education and Labor reported and the House passed a bill which was intended to prohibit any welfare payments to funds in which unions shared any control. See H.R. 3020 [Report No. 245] \$8(a)(2)(C)(ii), reprinted in 1 NLRB, LEgisLATIVE HistonY of the Labor Management Relations Act, 1947, pp. 31, 51 (1948); H.R. 3020 $\$ 8$ (a) (2) (C) (ii), reprinted in id. at 158, 178; H.R. REP. No. 245, 80th Cong., 1st Sess. 28 (1947). The text of the bill reported by the Senate Committee on Labor and Public Welfare contained no restraints on welfare payments, SEN. REP. No. 105, 80th Cong., 1st Sess. 31-47 (1947), but the supplemental report of Senators Taft, Ball, Donnel and Jenncr proposed an amendment, $i d$. at 53, which was subsequently adopted, 93 CoNG. ReC. 4754 (1947), as Section 302 of the Act. 
benefits. $^{101}$ In part, the insistence on employer representation may have been motivated by a fear that unilateral administration could be used as a club to discipline union members and prevent them from choosing a different bargaining representative in a subsequent NLRB election.

This requirement of joint central control by union and management representatives over pension funds was prospective only. It did not disturb existing unilateral arrangements. ${ }^{102}$ Before the Act's passage, approximately one-third of all persons covered by pension and welfare funds embodied in collective bargaining agreements were beneficiaries of funds administered solely by unions. ${ }^{103}$ These existing plans are presumably as subject to possible misuse as any that might be established in the future. Consequently, if exclusive union administration makes possible misuse or diversion of pension funds, the requirements of Section 302(c)(5) should have been extended to existing plans as well. Their immunization suggests either that Congress was reluctant to interfere with existing arrangements or that operation of these plans had revealed none of the dangers Section 302 (c)(5) was designed to prevent.

Even assuming, arguendo, that unions may misuse this type of fund, it does not follow that the further establishment of unilaterally administered funds should be prohibited. Other checks on fund disbursements appear adequate to prevent unauthorized diversion of pension funds. The TaltHartley Act, for example, requires that any payments to employee representatives for pension or annuity purposes must be made to a separate trust. ${ }^{104}$ The funds so accumulated cannot be used for purposes other than the paying of annuities or pensions; ${ }^{105}$ and the trust fund must be audited annually. The results of this audit must be made available for inspection

101. See Sen. Rep. No. 99, Part 2, 81st Cong., 2d Sess., 49 (1949). See also debates and reports cited note 100 supra.

102. Section $302(\mathrm{~g})$ of the Act, 61 STAT. 157 (1947), 29 U.S.C. $\$ 186(\mathrm{~g})$ (Supp. 1947), exempts trust funds established by collective agreement prior to Jan. 1, 1946 from the requirements of $\$ 302$ (c) (5) (B), 61 STAT. 157 (1947), 29 U.S.C. $\$ 186(c)(5)(B)$ (Supp. 1947). This clause has been interpreted by arbitrators to exempt contributions to funds in existence before Jan. 1, 1946 even though a particular employer did not contribute to the fund before that date. In $r e$ Harjer Furniture Ltd., 9 Lacos Ardimatio:: REPORTS 393 (1947). See also Upholsterers' Int. Union v. Leathercraft Furniture Co., 82 F. Supp. 570 (E.D. Pa. 1949) ; Fur Dressers Union v. Fur Dressers Guild, 18 U.S.L. WEEK 2290 (S.D.N.Y. Dec. 8, 1949). Since this interpretation was made known to Congress before 1949, Sen. Rep. No. 986, PART 1, S0th Cong., 2d Sess. 41 (1918), and neither the Taft bill, SEN. REP. No. 99, PART 2, 81st Cong., 1st Sess. 252-3 (1949), nor the Wood bill, 95 Cong. Rec 5650-1 (May 3, 1949), adopted by the Senate and House respectively, changed the Act's language with respect to exemption of existing funds, Congress appears to have acquiesced in this interpretation.

103. Bureau of Labor Statistics Bull. No. 841, Healta Berefit Prggrazis Estanlished Throvgh Collective Bargaining 1945, p. 2 (1945).

104. 61 STAT. 157 (1947), 29 U.S.C. $\$ 186$ (c) (5) (C) (Supp. 1947).

105. Ibid. 
by interested parties. ${ }^{106}$ Violations of these requirements can be enjoined, ${ }^{107}$ and the violators punished by fine and imprisonment. ${ }^{108}$ In the light of these provisions it seems unnecessary and unwise to prevent parties from providing for exclusive union administration where this procedure is mutually agreeable. ${ }^{109}$

\section{Private Pensions and The Problem of Old Age Security}

The wisdom of regarding private arrangements as an important element in an over-all social security plan is open to serious question. A minority, apparently growing, believes that old-age security is more appropriately a governmental than a private function. ${ }^{110}$ Their doubts arise largely from the inadequate coverage of plans now being established, from the uncertainty that full benefits will ever be paid by private plans, from the risks these plans leave uninsured, and from the possibility that these private pensions might have undesirable effects on an adequate program of social security for the nation as a whole.

106. 61 STAT. 157 (1947), 29 U.S.C. $\$ 186$ (c) (5) (B) (Supp. 1947).

107. 61 STAт. 157 (1947), 29 U.S.C. $\$ 186$ (e) (Supp. 1947).

108. 61 Stat. 157 (1947), 29 U.S.C. \& 186(d) (Supp. 1947).

109. There is a respectable difference of opinion outside as well as within Congress on the desirability of the Taft-Hartley Act restrictions. Major opposition in Congress has centered on the requirement of joint administration. See debates and reports cited note 100 sipra. Slichter feels the provisions have had predominantly good effects, Slichter, Taft-Hartley Act, 63 Q.J. EcoN. 1, 22-3 (1949). So does Professor Witte of Wisconsin: Witte, The Taft-Hartley Act in Operation: A Brief Appraisal, 2 Industrint \& Lanor ReL. REv. 403, 405 (1949). Secretary of Labor Tobin testified that while congressional action might be necessary to safeguard welfare funds, he did not think such legislation belonged in a basic labor relations law. He suggested the possibility of other supervisory legislation. Hearings before Committee on Labor and Public Wclfare on S. 249, 81st Cong., 1st Sess. 373 (1949). President Truman, in vetoing the Taft-Hartley Act, gave as one of his reasons the belief that the welfare trust fund clauses were too rigid, H.R. Doc. No. 334, 80th Cong., 1st Sess. 4 (1947). Mr. Arthur J. Goldberg, General Counsel, CIO, has repeatedly attacked the requirement of joint administration, Hearings supra, at 487-8; Hearings before Special Subcommittee on Education and Labor on H.R. 2032, 81st Cong., 1st Sess. 1427-9 (1949).

During the first session of the present Congress, the requirement of joint administration was scheduled for elimination, but the measure was lost in the battle over repeal of the Taft-Hartley Act, 61 Srat. 136 (1947), 29 U.S.C. $\$ 141$ (Supp. 1947). The bills reported out of House and Senate committees removed all restrictions on welfare funds. H.R. Rep. No. 317, 81st Cong., 1st Sess. 36-7 (1949) ; Sen. Rep. No. 99, 81st Cong., 1st Sess. 73-9 (1949). The Wood bill, adopted in the House, 95 Cong. Rec. 5641 (May 3, 1949), as an amendment for the committee bill, retained all the controls of the Taft-Hartley Act. See 95 Cong. Rec. 5650-1 (May 3, 1949). But in the Senate, the Tait bill, adopted as a substitute for the committee bill, 95 Cong. Rec. 8884 (June 30, 1949), permitted employers to waive the requirement of equal representation, and required the Secretary of Labor to certify that trust funds met requirements otherwise similar to those in the Taft-Hartley Act. SEn. Rep. No. 99, PART 2, 81st Cong., 1st Sess., 52-3 (1949).

110. Couper, Collective Bargaining on Pensions and Other Employee Bcnefit Plans in American Management Assoctation Personnel Series No. 123, Employee Beneris Plans and Collective Bargaining 3, 4 (1948). 


\section{Coverage}

Numerical coverage. The inadequacy of existing private pensions as a major factor in an over-all program of old-age security is illustrated by the small percentage of the nation's total working force presently covered by such plans. According to the latest estimates of the Social Security Administration, 7,000,000 employees, or slightly less than one-ninth of the nation's available working force, are covered by private industrial retirement plans. ${ }^{111}$ And the 250,000 retired persons now receiving benefits through pension plans made available by commercial and industrial organizations ${ }^{112}$ are relatively insignificant in comparison with the $10,500,000$ people aged sixtyfour or over in the United States. Even this high point has been attained only after a period of extraordinary profits, favorable tax laws and union activity.

Regional variations. Moreover, reliance on private pensions as an important part of a national security program may result in sharp regional differences in coverage. Different areas frequently contain differing concentrations of industrial activity to which private pensions are adaptable. As a result, the percentage of the population covered by these pension schemes may vary considerably from one part of the country to the other. Similar regional discrepancies in extent of coverage have already appeared in the administration of the old-age insurance portion of the Social Security Act. ${ }^{113}$ In both cases, these variations tend to place the burden of caring for the aged on states least able to bear it.

Correlation with union strength. This unsystematic coverage of employee

111. Communication to the Yale Law Jougnal from Mirs. Weltha Van Enam, Actuarial Mathematician, Social Security Administration, dated Nov. 23, 1949, in Yale Law: Library.

The status of private pension agreements has been in such flux that wholly reliable statistics are difficult to obtain. The latest Treasury Department statistics, which extend only to Aug. 31, 1946, indicate that 3,300,000 employees participate in plans approved by the Treasury. See Bureau of Internal Revenue (Income Tax Unit), Pcrsion Trust Statistical Tables Table 2. Plans approved numbered 6,862. Id. Through June 30, 1949, rulings had been issued with respect to $12, \$ 65$ pension and profit sharing plans submitted for qualification under INT. REv. CODE \$165(a), Communication to the YALE LAW JoursisL from W. G. Shreve, Head of Pension Trust Division, dated Oct. 18, 1949, in Yale Lav Library.

Some authorities estimate that as many as $10,500,000$ workers are now carning pension credits, communication to the YaLE LAW Jourana from Mliss Phyllis H. Mfoehrle, Industrial Relations Division, National Association of Mfanufacturers, dated Nov. 17, 1949, in Yale Law Library.

112. Dublin, Our Agtig Populatton 6 (1949).

113. 49 STAT. 620 (1935), as amended, 42 U.S.C. $\$ 301$ (1946). In June, 1948, for example, among every hundred aged persons living in Rhode Island and Connecticut, twenty or more were receiving federal old-age pensions. At the same time, in Mfississippi, North Dakota and South Dakota, fewer than five out of every hundred aged persons received benefits. The difference undoubtedly reflects the fact that a larger proportion of workers in the latter group of states are engaged in activities not presently covered by federal insurance. See Social Security Bull., Jan. 1949, p. 24. 
pensions also results from the apparently increasing correlation between - union strength and the existence or liberality of a pension program. Pension, health, and welfare programs embodied in collective bargaining agreements cover large numbers of workers in the coal, steel, electrical, automobile, street and electric railway, and clothing and textile industries. In each of these industries one or more well-established industrial unions is very active. ${ }^{114} \mathrm{By}$ way of contrast, craft unions generally have been slow in establishing pension plans. These unions have either lacked interest or have been unable to overcome the administrative difficulties of dealing with the proportionately large number of employers holding contracts with the individual unions. ${ }^{115}$ In addition, certain industries present specific problems which the unions involved have not yet been able to solve. In the logging industry, for example, the high mobility of operators and $\mathrm{cm}$ ployees has prevented the establishment of any pension programs. ${ }^{110}$ Insofar as an adequate old-age security program depends on private retirement programs, the net result has been coverage on a hit-or-miss basis.

Restrictions on membership. Even if the total number of plans were increased, many restrictive features limiting eligibility for participation in pension programs would retard their social usefulness. For example, subsequent to passage of the Social Security Act of $1935,{ }^{117}$ many plans limited coverage to employees earning over $\$ 3,000 .{ }^{118}$ But since the average basic old-age and survivor's insurance benefit is only $\$ 25$ a month, ${ }^{119}$ the need for additional income even for those earning less than $\$ 3,000$ annually is clear. Similarly, plans limited to salaried workers do nothing to relieve the needs of wage earners. ${ }^{120}$

A newer restrictive development is the tendency to make plans incor-

114. Sen. Rep. No. 986, Part 3, 80th Cong., 2d Sess. 90 (1948). See also Burenu of Labor Statistics Bull. No. 946, Employee Benefit Plans Under Collective Bargaining 3 (1948); Commission on the Organization of the Executive Brancur of the Government, Functions and Activities of the National. Government in ture FIELD OF WELFARE (prepared by the Brookings Institution) 502 (1949).

115. See Latimer, supra note 90 , at 5,6. One writer explains this by suggesting that craft unionists were highly independent and believed members should do their own saving. Heron, Beyond Collective Bargaining 72-3 (1948).

116. Communication to the Yale Law Journal from Virgil Burtz, Research and Education Director, International Woodworkers of America, dated Oct. 17, 1949, in Yale Law Library. See also Latimer, supra note 90, at 6.

117. 49 Stat. 620 (1935), as amended, 42 U.S.C. $\$ 301$ (1946).

118. See page 681 stpra. This restriction is apparently declining in popularity, Waters, Instred Pension Plans in American Managenent Ass'n Personnez Series No. 118, Trends in Employee Health and Pension Plans 12, 18 (1948).

119. Average benefits being paid at the end of the fiscal year 1948 were $\$ 25.60$ for each retired male worker without dependents. For each woman worker, they were $\$ 20.00$; for each retired worker and wife, $\$ 39.90$. REr. FSA 82 (1949).

120. This restriction also is declining in popularity, but its demise is a long way off. Lipton, supra note 42 , at 19 . Plans limited to salaried employees earning over $\$ 3,000$ annually are not, for this reason alone, deemed discriminatory by the Treasury. INT. REv. 
porated in collective bargaining agreements open only to members of the negotiating union. ${ }^{121}$ In certain highly unionized industries ${ }^{122}$ this may be the only practical way of administering a pension program. In other industries, however, the employer will be forced to adopt the uneconomical alternative of establishing a separate plan for non-union workers or else allow them to go unprotected. And restrictions that discriminate against nonunion members may constitute unfair labor practices. ${ }^{128}$

Some restrictions, moreover, delay membership in a plan until attainment of a certain age or completion of a minimum length of service. ${ }^{12 s}$ Labor turnover tends to be highest among young employees. ${ }^{125}$ Management therefore tries to eliminate unnecessary administrative expenses and possible insurance company surrender fees ${ }^{120}$ by barring recent and young employees from the program. ${ }^{127}$ But these restrictions also tend to shorten the period during which the worker could be earning retirement income. This

Cone $\$ 165(a)(5)$. For a discussion of possible effects of restrictions on employee relations see Gardner \& Weber, Tnistced Plans in Axrerican Minxagexnent Ass's Insursance Series No. 73, Trends in Retirearent Planinna 7, 8-10 (1948).

121. See Bureau of Labor Statistics Bull. No. 946, Eamloyee Betefit Plays UNDer Collective Bargaining 4 (1948).

122. For example, the needle trades. See page 698 and note 91 supra.

Ifaking pension plan membership dependent upon union membership has drawn sharp criticism from some quarters. The threat of expulsion, it is urged, gives union leaders a powerful weapon for maintaining discipline and rigid adherence to leaders' views. Sec, e.g., Sen. Rep. No. 986, Part 3, 80th Cong., 2d Sess. 94 (1948). These reasons are similar to those urged on behalf of joint administration of pension funds. Sce page 701 sipra.

123. Section $8(a)(3)$ of the Taft-Hartley Act, 61 STAT. 140, 29 U.S.C. $\$ 158(a)$ (3) (Supp. 1947), forbids an employer to discriminate with respect to hiring, tenure or any condition of employment "to encourage or discourage membership in any labor organizatron...." This provision was the basis of an injunction forbidding the URIW to demand a contract requiring employers to contribute to a pension fund providing benefits for union members only. See N.Y. Times, Feb. 12, 1950, p. 26, col. 6.

124. Until recently it was popular to require five years of service before an employee could become eligible for admission to a pension plan, O'NemL, Afoders Persion Plutis 196 (1947). This is sanctioned by INT. Rev. CodE $\$ 165(3)(3)(A)$. The minimum age provision tended to be thirty years, O'NemI, op. cit. sipra, at 195. Furthermore many plans contained provisions either limiting membership to those under a specified maximum age, usually between sixty and sixty-five, or specifying that no one hired after a certain age, usually forty-five or fifty, could join the plan. Id. at 196.

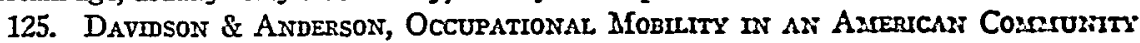
(1937), cited in McFarland, supra note 81 , at 515 . In addition to finding a high rate of turnover among employees under age twenty-five, Kitson also found age forty-one to fifty to be a crucial period. Kirson, The Psychology of Vochtromal Adjusturest 42-6 (1925). See note 131 infra.

126. See note 64 supra. If a trusteed plan is employed, some discount for withdrawals is possible, Kwasha, supra note 25 , at 7.

127. During the war, when turnover was abnormally high in many industries, it was perhaps justifable to impose these eligibility requirements. But unless one accepts the proposition that only relatively permanent employees should receive pension benefits, these 
results in either smaller retirement benefits or increased accumulation rates after membership in the program is granted. ${ }^{128}$

Restrictions on benefits. Although an employee may be eligible for membership in a pension plan, restrictions on length of service limit the number of members who will eventually receive benefits from the program. ${ }^{129}$ In several recent agreements, continuous service with the company for as many as thirty years is a condition of eligibility for maximum pension income. ${ }^{130}$ Frequently those not able to qualify for full benefits ${ }^{131}$ may receive a lesser

restrictions seem more difficult to justify today. See Maduro, Designing a Pension Plan in Handbook for Pension Planning 11, 13-14 (1949).

The 1948 survey of 289 programs by Bankers Trust Co. sheds light on recent practices. Plans are grouped by type of restriction on eligibility as follows:

\begin{tabular}{lcccc} 
Service Requirements & \multicolumn{5}{c}{ Number of Plans by Agc Requircments } \\
Age 25 and \\
No Age & Under & Age 30 & Age 35 \\
None & 37 & 2 & 4 & 1 \\
One Year & 34 & 9 & 18 & 8 \\
Two Years & 7 & 2 & 10 & 4 \\
Three Years & 17 & 7 & 10 & 5 \\
$\quad$ Four Years & 1 & & 1 & \\
$\quad$ Five Years & 42 & 8 & 37 & 24 \\
Special & & & 1 & \\
$\quad$ Total & 138 & 28 & 81 & 42
\end{tabular}

* Includes one plan having an age eligibility requirement of age 40.

Bankers Trust Company, 289 Retirement Plans 7 (1948).

128. See Jamison, supra note 10 , at 8.

129. Eligibility for full retirement benefits varies with the type of plan adopted and the basis on which benefits are determined. Self-administered plans frequently have both minimum service and age requirements, especially where no membership limitations are imposed, O'Neill, Modern Penston Plans 197-8 (1947). With insured plans there is ordinarily no arbitrary uniform service requirement. The requirement varies with the individual's age at the time he becomes eligible for membership in the plan. Id. at 268 .

130. The Bethlehem Steel agreement calls for maximum pensions after twenty-five years of service with the company, and for pensions reduced proportionately according to length of service for those having fifteen to twenty-five years' service. P-HI PENS1ON \& Profit Searing Serv. $\llbracket 1036, \S 3(\mathrm{~b})$ (2) (1947). The Ford agreement requires thirty years' service for full pensions. Id. at $\llbracket 1034, \S 5(\mathrm{a})$. The United Mine Workers fund requires twenty years' service in the industry. REQUIRENENTS of THE UNITED MiNE Workers of America Welfare and Retirement Fund For Eutginility For Penstons.

131. A recent survey of 128 firms located in New York State produced the following tabulation of average years service.

$\begin{array}{cc}\text { Age } & \text { with Present Enployer } \\ \text { Under } 21 & 1 \text { Year } \\ 21-40 & 5 \text { Years } \\ 41-50 & 10 \% / 2 \text { Years } \\ 51-55 & 13 \text { Years } \\ 56-60 & 14 \text { Years } \\ 61-65 & 16 \% \text { Years } \\ \text { Over } 65 & 172 / 3 \text { Years }\end{array}$

N.Y. State Joint Legislattve Committee on Problems of the Aging, Legrslative Doc. 1948, No. 61, p. 152, cited in Communication to the YALE LAW JourNAL from Eivan 
income, but, here again, eligibility for even the smaller benefits requires a minimum period of service, often ten or more years, plus attainment of a specified age. ${ }^{132}$ Those employed too late in life to permit attainment of the minimum service requirements receive nothing from the plan. ${ }^{138}$

\section{Certainly of receiving benefits}

Once a plan is established, employees have no guarantee that accrued benefits will ever be paid. Presumably, any contributions made to a pension fund represent deferred wage payments. Nevertheless, when employment is terminated for any reason other than retirement under the program, the employee loses his entire claim to whatever pension benefits he may have accumulated. ${ }^{134}$ Even if he remains in the employ of a single employer, he

Clague, Commissioner of Labor Statistics, dated Nov. 23, 1949, in Yale Law Library. Unfortunately, the Bureau of Labor Statistics has no more comprehensive results. Ibid.

132. See the summary of recent trends in Bankers Trust Cosrparry, 289 Retreserens Plans 7, 8 (1948). The survey reports some liberalization in this respect.

Where an employee is permitted to retire at an earlier than normal retirement age, he receives only the actuarial equivalent of his full benefit, often a very considerable reduction. O'Neml, Modern Pension Plans 199 (1947).

133. An employer, of course, can provide them with some benefits on an informal basis. But the fear that employers might be called upon to provide pensions for persons hired late in life is said to contribute to the reluctance of industry to hire older people N.Y. Times, Jan. 20, 1950, p. 20, col. 3. For indications of the increasing seriousness of the problem of discrimination against older workers in New York see N.Y. Times, Dee 7, 1949 , p. 35, col. 5.

134. The fact that under most plans the employee must remain with the company until retirement age in order to receive benefits has been one of the chief criticisms of private pensions. See, e.g., Robenns, op. cit. sutpra note 32, at 22-6; Slichter, The Pressing Problem of Old-Age Security, N.Y. Times MFagazine, Oct. 16, 1949, p. 9 at 66, col. 3, and at 67, col. 3. See also comments of Cyrus S. Ching, Director of the Federal Afediation and Conciliation Service, reported in N.Y. Times, Nov. 29, 1949, p. 20, col. 7 ; and Dr. Clark Kerr, Director of Institute of Industrial Relations, Univ. of Calif, reported in N.Y. Times, Nov. 23, 1949, p. 18, col. 3; and see N.Y. Times, Nov. 6, 1949, \$4, p. 7, col. 1, 3.

Immediate full vesting of pension rights is an ultimate objective for unions negotiating pension plans, but its realization may be in the distant future, see Relirement Plons in Collective Bargaining Part IV, AFL Research Report, Oct. 1949, p. [3]. In 1942, Counsel General Randolph Paul recommended that partial vesting be made a condition for approval of plans under INr. Rev. CODE \$165(a), Hearings before House Committee on Ways and ITeans on Revenue Revision of 1942, pp. 10045 (1942), but the proposal was lost in a storm of protest.

The following table indicates the divergence of vesting practices.

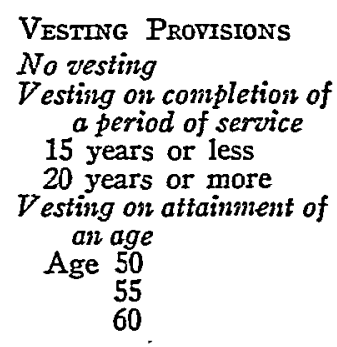

\begin{tabular}{|c|c|c|}
\hline $\begin{array}{l}\text { Nuaraer of } \\
\text { PlaAs }\end{array}$ & $\begin{array}{c}\text { SUR- } \\
\text { TOTALS } \\
69\end{array}$ & $\begin{array}{c}\text { PER CE:IT } \\
\text { OF PLAIS } \\
23.9 \% \circ\end{array}$ \\
\hline
\end{tabular}

41

$17 \quad 58 \quad 20.0$

1

21

39 
can never be sure that the plan will not be abandoned before his benefits become due. ${ }^{135}$ Some pension plans are revocable at the employer's discretion. ${ }^{136}$ And some irrevocable plans are established by collective bargaining agreements that bind union and employer for only a short period. ${ }^{137}$ Hence there is no guarantee that future union agreements will authorize continuance of the pension scheme. And the possibility of business failure adds further uncertainty to the eventual fruition of the plan. Statutory or contract provisions for immediate vesting of employee rights might provide security of payment as long as an enterprise remains solvent; they would be of limited use in the event of business failure. ${ }^{133}$ Many employers today feel

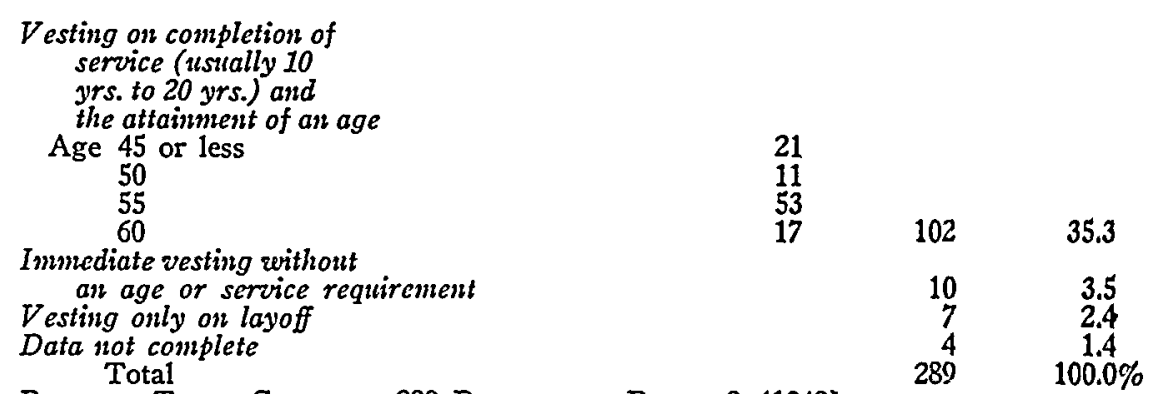

Bankers Trust Conipany, 289 Retirement Plans 8 (1948).

Although current practices are more liberal than those of several years ago, Couper, Present-Day Pension Problems, 11 Managenent Recond 4 (1949), immediate full vesting is a distant goal, and the most recent plans continue these typical limitations. See N.Y. Times, Dec. 31, 1949, p. 18, col. 6.

135. See page 680 supra for discussion of the plans dropped cluring the $1930^{\prime} \mathrm{s}$. Failures during the preceding decade are fully described in Edwards, Indistrial Pension Plans Collapsing, Annalist, Nov. 20, 1925, p. 637, col. 1 ; and Edwards, The Way Out of the Industrial Pension Crisis, Annalist, Nov. 27, 1925, p. 667, col. 1.

136. One of the two types of clauses frequently employed provides that the company may cancel the plan at any time without incurring any liability to employces. See, e.g., Swifr \& Co. Pension Pian 10 (1948). The other leaves the company free to cancel the plan, but protects participants' rights to retirement income units already purchased. See, e.g., Employees Retirement Allowance Plan of Sinclair Oil Corp. 43 (as amended July 1, 1947).

137. The Ford agreement is to continue in effect for five years following March 1 , 1950, P-H Pension \& Profit Sharing Serv. II 1034, \$14 (1947), Bethlehem's plan will continue until Dec. 31, 1951, and, if no changes are made, until Oct. 31, 1954. Id. at I $1036, \S 15$.

138. Query whether $\$ 64$ of the Bankruptcy Act, 30 Star. 563 (1898), as amended, 11 U.S.C. $\$ 104(\mathrm{a})(2)$ (1946), which gives wages a priority, affords much protection. Assuming that pension contributions are "wages" within the meaning of the section, what effect is to be given to the requirement that "wages not to exceed $\$ 600$ [must] . . . have been earned within three months before the date of the commencement of the proceeding ...."? Clearly this would exclude an employee who has been receiving a pension for several years. Where a pensioner had no rights in a plan until he attained age sixtyfive, and where proceedings in bankruptcy were commenced the day after retirement, what result? Would he have a preferred debt for so much of the cntire annuity as did not exceed $\$ 600$ on the theory that he earned it the day he retired? What about employees who have no present pension rights at the time of the proceedings, but who have "carned" 
that they are being forced by union pressure to make promises which they will not be able to fulfill unless national income remains at current high levels. ${ }^{139}$ While only the future can test the validity of this belief it is certain that a government old-age security program offers beneficiaries greater certainty of receiving benefits.

In partial mitigation of these factors, the Internal Revenue Code offers some assurance of permanency to a pension plan. For to meet Bureau of Internal Revenue qualifications, pension trust funds must be irrevocable, ${ }^{163}$ and pension plans must be "permanent." This requirement of permanency does not prevent an employer from revoking a pension program at will. But if he revokes "within a few years" following the plan's establishment for any reason other than "business necessity," he may be taxed on the contributions previously deducted as business expenses. ${ }^{1 \& 1}$

contributions during the preceding three months? Would the courts adopt an allocation scheme as they do in vacation pay cases? See cases cited in 3 Concrer or: Bariknurzcr 2088 (Moore \& Oglebay ed., Cum. Supp. 1949). And what of the employee who has authorized deductions from his pay which are still in the employer's hands? Would the subsequent debt have arisen from this "contract" and not from wages?

139. See, e.g., Arends, Pension Vieus and Previeus, 83 Trusts \& Estates 292, 294 (1949) ; Hammer, The Futture of Pcnsion and Bensefit Plans, N.Y. Journal of Commerce, May 15, 1944, §2, p. 57; Jamison, stpra note 10, at 15-16; N.Y. Times, Jan. 3, 1950, p. 51, col. 1; Slichter, The Pressing Problcn of Old-Age Security, N.Y. Times Aragazine, Oct. 16,1949, p. 9 at 67 , col. 3.

Adequate statistical information is lacking concerning the size of non-wage benefits in relation to the total wage bill for business in general or for most specific industries. For a limited study see Econonstc Research Dep'x, Chazmer of Counrence of tue U.S.A., THE HIDDEN PAYroll (1949). This report contains no statistics to indicate to what extent pension premiums and payments alone have added to the total wage bill for given industries.

Expansion of private plans has raised doubts that the economy can stand the cost of continuous employer payments to funds which must, in many cases, pay hundred-dollar-amonth pensions in the future. See, e.g., N.Y. Times, Nov. 23, 1949, p. 18, col. 3 ; Editorial, N.Y. Times, Nov. 30, 1949, p. 26, col. 1. But for an optimistic view of national capacity to support expanded old-age security benefits see Couxcrl of Ecoxosnc Aonsons, BusINess AND Governarent 21-3 (Fourth Annual Report to the President, 1949).

One suggestion is that employers guard against future adverse business conditions by including clauses in negotiated plans permitting employers to terminate them for reasons of business necessity. See Schwartz, Pension and Relirement Programs, CCH Labor I.J., Oct. 1949, pp. 25, 28. But this assumes that unions will be willing to accept such clauses. Studies of negotiated plans reveal frequent use of provisions authorizing discontinuance of pensions during the term of the contract only with the consent of both the union and the employer. See Brower, Benefit Programs in Union Agrecments, 10 MLANAgEMEN RECORD 595-6 (1948). Latimer suggests that the wording of most social security contract clauses implies a long duration with periodic adjustments of details, Latimer, supra note 90 , at 12-13. For a compilation of pension agreement clauses see Hearings before Comnnittee on Banking and Currency Connmilfec on Economic Pouter of Labor Organizations, 81st Cong., 1st Sess. 391-409; Burenu of Laros Statistics, Collective Bargatning Provisions-Earployee Benefir Plans.

140. INT. Rev. Code $\$ 165$ (a) (2).

141. See U.S. Treas. Reg. 111, $\$ 29.165-1$ (1943), and Ruling of the Pension Trust Division No. 52 (Aug. 9, 1945). 
The employee may seek redress in the courts to recover his promised pension. But the conditions under which the courts will find such employee interests worthy of protection have yet to be fully determined.142 In the final analysis, the employee must look to his union and to public opinion as a source of protection for his "vested" rights to the benefits he has earned.

\section{Uninsured Risks}

Intense union activity has helped liberalize many restrictive features of pension plans. ${ }^{143}$ But there are several areas of need which are beyond the scope of private arrangements.

The unemployables. Approximately 2,000,000 Americans are persons with low employability. For various physiological and psychological reasons, these people work only intermittently. They are likely to change jobs frequently. Hence, they rarely remain with one employer long enough to qualify for pension benefits; and they tend to become unemployed quickly in periods of decreased business activity. ${ }^{144}$ Private pensions are not adaptable to this group.

The dependents. Private pensions do not make adequate provision for the dependents of a pensioner after his death. ${ }^{145}$ Some annuity payment plans do guarantee income for a certain period even beyond the pensioner's death. ${ }^{146}$ This arrangement, however, is only partially satisfactory. If the pensioner dies before the end of the period for which payment is guaranteed, the unpaid balance may go to persons not actually dependent on him. ${ }^{147}$ Still other pension schemes permit the pensioner to elect payment for the duration of his own or his wife's life, whichever is the longer. ${ }^{148}$ These pay-

142. For a summary of court treatment see Note, Legality of Prizate Pchsion Plans, 20 NeB. L. REv. 53 (1941).

143. See Kwasha, supra note 25, at 7 ; for a general discussion of recent trends sce Couper, Present-Day Pension Problems, 11 Managenent Recond 4 (1949).

144. Slichter, Soctal Security After the War 5-6 (1943).

145. Gardner \& Weber, Trusteed Plans in American Management Ass'N Insunance Series No. 73, Trends in Retirement Planning 12 (1948).

146. This arrangement, known as an annuity certain and continuous, is found more frequently among smaller companies than among larger ones. Maduro, Designing a Pension Plan in Handook for Pension Planning 11, 35 (1949). Under these plans, the annuitant receives payments even if he lives beyond the set period, but in this case, his dependents receive nothing at the time of his death. The annuity certain and continuous is discussed in O'Neill, Modern Pension Plans 61 (1947).

147. Gardner \& Weber, Trusteed Plans in American Management Ass'N Insunance Sertes No. 73, Trends in Retirement Planning 7, 12 (1948).

148. This arrangement, sometimes called a contingent annuity option, is frequently adapted to larger plans, Maduro, Designing a Pension Plan in HANDwook ror PENsion Planning 11, 34-5 (1949). Unlike the annuity certain and continuous, note 146 stipra, it promises nothing to the beneficiary in his own right. In essence, it permits the annuitant to elect, in advance of retirement, to receive a reduced income for his life in exchange for the insurance company's promise to continue payments for the life of a surviving dependent. O'Neili, Modern Pension Plans 120 (1947).

In the recent steel settlements, where trust funding was adopted, no special mention of dependents was made, P-H Pension \& Profit Sharing Serv. If 1036, 1038 (1947). Per- 
ments are usually only the actuarial equivalent of what otherwise would have been paid to the pensioner himself for life. ${ }^{169}$ Consequently individual payments are small.

The disabled. Private action ${ }^{150}$ has as yet done little to meet the problem of economic security for the permanently and totally disabled. ${ }^{151}$ Although more than sixty insurance companies offer at least partial protection against this type of loss, few individuals purchase it. The cost is high and the terms on which it is offered are restricted. ${ }^{152}$ Because of substantial losses incurred in the past, insurance companies do not include permanent and total dis-

haps, however, some options similar to those available with group annuities will be offered to the employee as he nears retirement age.

149. Maduro, Designing a Pension Plan in Handeoor for Pensron Planiring 11, 35 (1949). When the annuity certain and continuous is employed, increased costs must be anticipated. Ibid.

By way of contrast, Federal Social Security provides surviving dependents' protection. If the act's requirements are met, this protection extends to wives of individuals themselves entitled to benefits, 53 STAT. 1364 (1939), 42 U.S.C. $\$ 402(b)$ (1946); to dependent children, 53 STAT. 1364-5 (1939), 42 U.S.C. $\$ 402$ (c) (1946); to widows, 53 SraT. 1365 (1939), 42 U.S.C. $\$ 402(d), \S 402(\mathrm{e})$ (1946); and to dependent parents, 53 Stat. 1366 (1939), 42 U.S.C. $\$ 402(f)$ (1946). But since each contributor pays the same percentage of payroll tax regardless of the number of dependents, benefits ultimately received bear no necessary relation to the amount contributed by the individual annuitant. Deficiencies in any particular account must therefore be made up from the contributions of others or from general tax receipts.

150. The Federal Government is only beginning to consider seriously a national program of permanent and total disability insurance. The Social Security Act, 49 Srat. 620 (1935), as amended, 42 U.S.C. $\$ 301$ (1946), contains no such provisions. The Advisory Council on Social Security recommended that permanent and total disability benefits be paid to those meeting rather strict tests of eligibility, SEN. Doc. No. 208, 80th Cong., 2d Sess. 72-3 (1949). These requirements were made less severe in the Doughton bill, H.R. 600, 81st Cong., 1st Sess., now before the Senate Finance Committce It provides for disability payments to the insured employee only, commencing six months following the month in which disability occurred. Among other things, the bill requires that the claimant must have had six quarters of coverage (employment in jobs covered by the bill at earnings above a minimum) within the thirteen quarter period preceding disability, and twenty quarters of coverage within the forty quarter period preceding disability. Sce H.R. REP. No. 1300, 81st Cong., 1st Sess. 7, 104-10 (1949).

151. Hamilton, supra note 57, at 587; Altmeyer, Social Security and Wclfare Funds in Nationai Industrial Conference Board Studies in Busimess Econosics No. 8, Union Health and Welfare Funds 22, 24 (1947). There is an average of 2,000,000 persons in the United States who have been kept from gainful employment for six months or more. SEN. Doc. No. 208, 80th Cong., 2d Sess. 69 (1949). Losses from work-connected disability are, of course, partially compensated by workmen's compensation, but less than five per cent of all permanent and total disability cases are of work-connected origin. Ibid. One of the difficulties of studying the problem in the United States is the inadequacy of statistical sources. See Soctal Security Board Bureau of Resentcr ain Statistics Miemorandums No. 61, Disabitity Among Gannfully Occupied Persons 2, 3 (1945), a valuable preliminary survey.

152. SEN. Doc. No. 208, 80th Cong., 2d Sess. 69 (1949). Individual policies occasionally contain a waiver of premiums in the event of disability. GArdres \& IVEBER, PE:ision, Bonus, and Profit-Sharing Plans 45 (1943). 
ability provisions in their group annuity policies. Where a pension trust is employed, payments can be made directly from the fund according to the terms of the plan or agreement. ${ }^{153}$ Even where disability provisions are included, however, eligibility is greatly restricted by requirements of long periods of service or the attainment of a minimum age, or both. ${ }^{104}$

\section{Future Effects}

Because most plans require employees to remain at one job for a long period of time in order to secure pension benefits, ${ }^{165}$ some writers urge that private pensions will tend to restrict the mobility of labor. ${ }^{168}$ Theoretically, mobility can be preserved by provisions for the transfer of earned pension credits from one employer to another when an employee changes jobs. But existing plans overwhelmingly reject this possibility. ${ }^{157}$ It is clear that only a national system can achieve the objectives of free labor mobility ${ }^{169}$ and constantly-accruing pension credits. But the existence of pension plans may not burden labor mobility to the extent that has been predicted. The promise of a pension at age sixty-five may mean little to younger employees, ${ }^{169}$ generally the most mobile group. ${ }^{160}$

153. See page 692 supra. Early union pension efforts also inclucled some attempts to cope with the disability problem. See Latimer, Trade Union Pension Systens 51 (1932). But aside from the railroad brotherhoods, few unions currently pay disability benefits, Dankert, Contemporary Unionism in the United States 238 (1948).

154. The steel agreements illustrate cautious advances in the direction of adcrutate protection. The Bethlehem and United States Steel plans provide that the disabled person must have had at least fifteen years of previous continuous service, his disability must have come from some "unavoidable cause," he must be unable to engage in any paying occupation, and, after his disability has continued for six months, a physician must certify that it will continue for the remainder of his life. P-H Pension \& Prorit Sunring SEuv. \I 1036, § 4 (1947); id. at I 1038, Part II, § I, 2 (1947).

155. See pages 706-7 and note 134 supra.

156. See, e.g., New Republic, Oct. 10, 1949, p. 5; N.Y. Times, Nov. 23,1949 , p. 18, col. 3; Slichter, The Pressing Problem of Old-Age Sccurity, N.Y. Times Magazine, Oct. 16,1949, p. 9 at 66, col. 3.

157. See table, note 134 sipra.

158. Excessive labor turnover, of course, is not desirable from an individual business and national point of view. See, generally, Douglas, Labor Turnover in 8 ENcYc. Soc. SCr. 709-10 (1932) ; Fisher \& HANNA, T He Dissatisfied Worken 233-4 (1931); KitsoN, The Psychology of Vocational. Adjustament 33-41 (1925). See also the studies of absenteeism and labor turnover in Mayo, The Soctal Problens of an Industrial Civirization c. V (1945). Reduction of labor turnover is, in fact, one of the objectives of private pensions.

Local studies of labor migrations give some indication of American labor's mobility. Among 1,100 domestic servants employed in private homes in one eastern city, at sometime between 1936 and 1942 ten per cent had recently worked in employment covered by Federal Social Security. Corson, The Old-Age and Survivors Insurance Program in War and Post-War Soctal Security 58, 62 (Cohen ed. 1942).

159. See, e.g., O'Neill, Modern Pension Plans 196 (1947).

160. See page 705 and note 125 supra. 
The prediction that private pensions might lessen the interest of labor in the promotion of national social legislation ${ }^{101}$ requires close analysis. This viewpoint finds support in the fact that the immediate needs of workers represented by some of the more powerful unions are being partially met. Moreover, an increase in federal old-age security would actually narrow the gains some unions now are making. For example, the recent agreements in the automobile and steel industries require the employers to pay only the difference between guaranteed pensions and any social security benefits. ${ }^{162}$ Since these settlements provide for non-contributory pensions, the worker now has no pension deductions made from his pay. In order to finance the benefits promised by the new Social Security Bill, ${ }^{163}$ however, workers will be required to pay higher payroll taxes. ${ }^{104}$ Therefore, if the bill should become law, workers will be contributing to the government for exactly the same benefits which industry alone must now provide. ${ }^{105}$

Dynamic and aggressive union groups, like the auto workers, are nevertheless unlikely to slacken their efforts to secure higher benefits under a broader social security program. ${ }^{\text {If }}$ For example, nothing prevents a union from seeking additional benefits through a private pension plan, no matter what the scale of benefits under social security may be. And progressive unions will probably continue to be interested in extending social security coverage and benefits to less fortunate workers in industries where pension

161. See Jensen, Penzions and Retirentent Plans as a Subject of Colleclize Bargaining, 2 Industrial \& I Agor ReL. Rev. 227, 235 (1949); comment of Dr. Eveline Mr. Burns, Professor of Social Work, N.Y. School of Social Work, reported in N.Y. Times, Dec. 2, 1949 , p. 5 , col. 2 .

162. P-H Pension \& Profit Sharing Serp. \1034, §5(a) (1947); id. at I 1038, §II, 2 (1947).

163. H.R. 6000, 81st Cong., 1st Sess. (1949).

164. H.R. 6000, approved by the House of Representatives without amendment, 95 Cong. Rec. 14241 (Oct. 5, 1949), provides for the imposition of payroll taxes paid by employees according to the following schedule:

For the calendar year 1950,11/2\%

For the calendar years 1951 to 1959 , inclusive $2 \%$

For the calendar years 1960 to 1964 , inclusive $2 \pi / 2 \%$

For the calendar years 1965 to 1969 , inclusive 3\%

For the calendar years 1970 and subsequent calendar years $3 / 4 \%$

H.R. REP. No. 1300, 81st Cong., 1st Sess. 117 (1949).

The present schedule fixes the employee's tax at one and one-half per cent of his payroll for 1950 and 1951, and two per cent thereafter. INT. REv. CoDE $\$ \$ 1400(2)$, (3).

165. According to one analysis, if the House-approved payroll tax increases go into effect, the total contribution of Ford will be decreased by one and one-eighth cents per hour while that of Ford workers will increase one and five-eighths cents per hour. ILWU Research Dep't, Ford UAW "Retirement" Plan, Oct. 24, 1949, p. 2.

166. Experience to date does not seem to indicate any lessened union interest in brosdening social security benefits. See Letter to the Editor from Louis Hollander, President, N.Y. State CIO Council, N.Y. Times, Dec 6, 1949, p. 30, col. 7; N.Y. Times, Jan. 2, 1950, p. 8, col. 1; N.Y. Times, Jan. 15, 1950, p. 47, col. 3; N.Y. Times, Feb. 2, 1950, p. 17, col. 8 . 
plans have not yet been established. These unions and particularly their leaders recognize that they cannot hope to secure ever increasing benefits themselves while other sectors of the labor force lag behind. And in fact, there is reason to believe that union leaders sometimes deliberately consent to contract provisions tying pension plan benefits to social security payments in order to overcome employer opposition to further expansion of the social security program. For larger benefits under social security, financed by a payroll tax, will correlatively reduce employer contributions to a pension fund. Instead of opposing further expansion of social security, therefore, employers saddled with a non-contributory pension plan are likely to favor it.

\section{ConCLUSION}

So long as federal old-age insurance remains inadequate, private pension plans help meet a vital need. ${ }^{167}$ But at best they are no substitute for a comprehensive national social security program-adequate as to benefits and adequate as to coverage. These private plans are too restricted in their coverage ever to provide assured retirement income for all superannuated workers who may be in need of it. And even if these restrictions were liberalized or removed, a broad area of risks would remain for which no adequate private pension plan could be devised. Only a government program can achieve the goal of complete coverage, encompassing all possible risks and providing assured benefits.

167. Present labor activity in the pension field is clearly motivated to a large degree by the failure of the Federal Government to enact even a satisfactory minimum social security program. See e.g., MIURRay, Report to the CIO, Tenth Constitutional Convention 14-15 (1948) ; UAW-CIO, Collective Bargaining Handnook for WorkERS Security Programs 5 (Revised Oct., 1949). See also Minkoff, supra note 17, at 24. 